\title{
Analysis of the Territorial Issue regarding the Liancourt Rocks between Korea and Japan
}

\author{
Min Jung Chung \\ Legislative Research Officer, National Assembly Research Service, \\ Seoul, Republic of Korea \\ minjch@assembly.go.kr
}

\begin{abstract}
In this Article, the "three-staged judicial review" found in the reasoning of territorial arbitral awards of the International Arbitral Tribunal and decisions of the Permanent Court of International Justice and the International Court of Justice, was discussed. The Tribunal and Court have attributed the utmost priority to boundary treaties (in most cases, concluded between two imperial nations in the past), peace treaties, uti possidetis juris, and an adjudicative award in adjudicating the sovereign matter. Conversely, a chain-of-title through cession and succession from ancient times is of no value. In the absence of any legal title, then effectivités is taken into consideration.

One of the rationales behind the reasoning was that the principle of stability of boundaries is of such importance that it may defeat other principles of international law, e.g., even jus cogens. It is, however, suspected that contemporary reasoning demonstrates bias toward maintaining past colonial rule under the guise of the stability of boundaries. Domestic property law and economics approach also explains that a state with written title (based on boundary treaties, peace treaties, the principle of uti possidetis, and arbitral awards) and a state with effectivités are more likely to be considered to have control over territory in issue than a state with original ownership.

As to the issue of the Liancourt Rocks, Japan claims that it will be necessary for Korea and Japan to diplomatically negotiate to refer the matter to the Tribunal or the Court. However, Korea does not feel the need to agree on referring the matter to the International Judicial Body. The first reason for Korea's attitude is that Korea already physically occupied the island with its police force. The second reason is that Japan has a choice, either to take the island back with direct confrontation or to accept the loss and leave Korea's sovereignty alone, that the Liancourt Rocks has of little value to Japan, compared to other territories disputed between Japan and its neighboring states, and therefore, that it is almost impossible to imagine that Japan would dare
\end{abstract}


to choose direct confrontation. There are likely to be many more reasons for leaving Korea's sovereignty over the Liancourt Rocks alone than for initiating military operation over the small island. The third reason is that, although Korea is more likely to win the case given the reasoning and its three rationales above mentioned, Korea's ownership of this island would become a fait accompli without taking unnecessary risk of deferring the sovereign matter of critical national interest to the third judicial body.

\section{Keywords}

Liancourt Rocks - three-staged judicial review - peace treaties - treaties concerning boundary delimitation - International Court of Justice

\section{Introduction}

Sovereignty over the Liancourt Rocks has been disputed since the Republic of Korea achieved independence from the imperial control of Japan.* The islands are known as Dokdo in Korea, Takeshima in Japan while western explorers and writers have referred to them as the Liancourt Rocks since French warship named Liancourt called Dokdo/Takeshima Liancourt Rocks in 1849. Korea physically occupies the island and Japan protest continuously against the administrative measures of Korea in an effort to prevent Korea from acquiring a title for the Liancourt Rocks through effectivités or prescription, arguing for review by the International Court of Justice concerning the sovereign title over the island. Currently, Korea and Japan are far from reaching an agreement to submit the territorial issue regarding the Liancourt Rocks to judicial review by the international society because Korea has resisted calls for formal legal oversight of the sovereignty over the territory. Korea advocates the opinion that additional legal authority from the international society is not necessary. Additionally, Korea is also uneasy concerning the adequacy of judicial oversight of the International Court of Justice because current decisions of the Court, with regard to territorial sovereignty, are prejudiced against the pastcolonized nation. Korea fears that the bias may lead to defeat in opposition to the sense of justice, even though in conformity with the rule of law. However,

\footnotetext{
* A significant portion of this Article is excerpted from the author's J.S.D. (Degree of Doctor of the Science of Law) dissertation. See Min Jung Chung, Analysis of the Territorial Issue regarding the Island of Liancourt Rocks between Korea and Japan, School of Law (Boalt Hall), University of California at Berkeley (May 12, 2007).
} 
the resistance of the Korean administration to direct talks could prove costly to the long-term interests of Korea.

Actually, Koreans are uncomfortable about the potential for the future bold actions (e.g., pre-emptive military response) from the Japanese government, which must not be allowed to occur at any cost. Japan is also concerned with the continuous physical occupation of the territory by Korea since independence. Considering the characteristics of international law respecting stability of boundary, status quo and fait accompli, time is not on the side of Japan. Therefore, both countries need to understand the interaction between diplomatic and judicial means of land dispute settlement so that both countries can work towards a compromise and solution to remedy the colonized party, Korea, in a manner acceptable to both parties. In political negotiations between Seoul and Tokyo, Japan would be offered the opportunity of referring the issue to the Court, otherwise seemingly impossible, in exchange for verifiably abandoning the legal benefit arising from the consequence of past imperialism. In turn, Korea would be offered a fair possibility to improve its reputation from that of an illegal occupant to a legitimate owner through a new applicable law, agreed upon by both parties, based on a sense of historic justice in exchange for current benefits resulting from physical occupation of the Liancourt Rocks. Political negotiation with Japan may fail to produce an acceptable agreement. But, considering the long-term interests of Korea, by testing the willingness of Japan to bargain seriously and by showing that the Japanese rejection of reconciliation hinders negotiations, Korea would put itself in a stronger diplomatic position to seek worldwide international support. Best of all, the talks just might succeed and lead to reconciliation between two nations. Unless the Korean administration eases its stubborn opposition to directly addressing the territorial dispute, it is difficult to vision what will stop the current diplomatic confrontation over the territorial issue regarding the Liancourt Rocks and the eventual emergence of a conflict between Korea and Japan.

In this Article, the reasoning that has appeared in leading arbitral awards and judgments concerning territorial disputes will be applied to the disagreement between the Republic of Korea and Japan over the territorial issue regarding the Liancourt Rocks. First, this Article will describe the factual background and conflicting claims over the Liancourt Rocks. Second, the relevant cases on territorial disputes will be explained and analyzed. Third, the Article will map out the coherent jurisprudence which international adjudicators should be subject to when deciding land and boundary disputes. The Article specifically names it the "Three-Staged Judicial Review." Finally, the current reasoning scheme will be applied to the territorial issue regarding the Liancourt Rocks now waiting to resolution between the Republic of Korea and Japan. 


\subsection{Historical Background}

2.1.1 Governance of Korean Dynasties over the Island

The original, historic and ancient title claimed by Korea is dated from the sixth century based on discovery and effectivités by Korean predecessor, while the claim by Japan is traced to the sixteenth century. Samguk Sagi (History of the Three Kingdoms) states that Silla, one of the three ancient Korean kingdoms, conquered and annexed Usan-guk (Usan-state) in 512 AD. ${ }^{1}$ As Koreans generally believe, the Liancourt Rocks, coupled with Ullungdo, was subjugated to Silla since the Usan-State comprised both Ullungdo and the Liancourt Rocks. ${ }^{2}$

The first direct historical reference to "Usando" (the Liancourt Rocks) as opposed to Ullugndo can be found in Sejong Sillok (Annals of King Sejong), in which it was stated, in a chapter describing its territory, that "Usan and Mullung [Ullungdo] are located in the midst of the sea just to the eastern direction of this prefecture. The distance between these two islands is not so far that these two islands can be seen from each other on a clear day."3

The Japanese side endeavors to undermine the authenticity of these Korean historical records by quoting the section on Uljinhyon in the Chiriji (Gazetteer) in Koryosa (History of Korea, 1451) which describes Usan and Ullung (Mullung) as two different names of the same island. ${ }^{4}$ Conversely, Korea refutes that Usan and Mullung were originally two separate islands since the demise of the Usan-guk, which had been the ancient mini-State governing two islands.

\subsubsection{Policy of the Island Empty during the Chosun Dynasty}

As the Chosun dynasty (immediate predecessor of the Korean Government between 1542 and 1910) emerged, Ullungdo (not to mention the Liancourt Rocks attached to Ullungdo) became a shelter for the displaced people of the

1 Kim, Pu-sik, comp., Samguk Sagi (History of the Three Kingdoms) (1146), Vol. 4: Silla Pon'gi (Annals of the Kingdom of Silla); reprinted in Park, Hee Kwon \& Bae, Jong-In, "Korea's Territorial Sovereignty over Tokdo", 29 Korea Observer 121, 134 (1998).

2 For instance, Mangi Yoram (Handbook of State Affairs) of 1808 quotes Yojiji (Gazetteer) in its chapter on military administration: "Ullungdo and Usado were lands all belonging to the former Usan-State, and Usando was none other than what the Japanese call Matsushima (the Liancourt Rocks)." Kunjong Pyon (Military Administration)" in Mangi Yoram (Sim, Sang-gyu et. al. (eds.), 1808); reprinted in Park, Hee Kwon \& Bae, Jong-In, supra note1, at 134).

3 Chiriji (Gazetteer) in Sejong Sillok (Annals of King Sejong compiled and published by the Chosun Dynasty government in 1454), Vol. 153, Section on Uljinhyon, Kangwondo.

4 It reads that "Ullungdo is situated in the midst of the East Sea [Sea of Japan] and was called Usan-guk during the Silla Dynasty. It is also known as Mullung or Ullung." 
preceding Koryo dynasty, who sought to evade taxes and military service. ${ }^{5}$ Moreover, the island was exposed to frequent pillaging by Japanese pirates. This led the government to enforce a policy that the island empty in 1417 , forbade the settlement of Koreans on Ullungdo and left the island uninhabited. ${ }^{6}$ The island continued in the empty state for about 400 years. ${ }^{7}$

2.1.3

Activities of Japanese Fishermen on Ullungdo and the Liancourt Rocks

While Ullungdo remained uninhabited in accordance with a Korean Dynasty's policy that the island empty, some Japanese fishermen occasionally sailed to Ullungdo. Japanese primary claim to the historic title to the Liancourt Rocks is based on the fact that Japanese fishermen worked on and around the Liancourt Rocks.

Korea makes three allegations against the activities of Japanese fishermen. Firstly, they were acting as private citizens, not as a sovereign act of the government, and therefore, they should not impact the matter of sovereignty over the Liancourt Rocks. Secondly, Korean fishermen likewise fished along the southern and eastern coasts in the rich fishing grounds off Ullungdo, although the government of the Chosun Dynasty adhered to the policy that the island be uninhabited. Thirdly, the Chosun Dynasty exercised a sovereign act by administering the policy for the reason of national security, while the Japanese government at that time issued "permits for passage" to the island to Japanese seamen. ${ }^{8}$ According to the Korean claim, the issuance of permits demonstrates that the Japanese government then recognized that the Liancourt Rocks were foreign territory that required the need to issue permits to its nationals who tried to cross the border.

5 Lee, Han Key, “Korea's Territorial Rights to Tokdo in History and International Law", 29 Korea Observer 1, 26 (1998).

6 Park, Hee Kwon \& Bae, Jong-In, supra note 1, at 138.

7 Lee, Han Key, supra note 5, at 26.

8 In 1618, Otani Jinkich and Murakawa Ichibei of Yoango applied to the Japanese government for a license to sail to Ullungdo. Upon obtaining the license in 1618, the Otani and Murakawa clans alternately dispatched ships to Ullungdo, mainly for logging purposes. In 1661, they also received a permit for passage to Matsushima (the Liancourt Rocks) and appear to have engaged in occasional fishing activities off the islet. Japan contends that these permits by Tokugawa Shogunate for two Japanese clans to sail to and utilize both Takeshima (Ullungdo) and Matsushima (the Liancourt Rocks) amount to display of sovereignty over the two islands. Park, Hee Kwon \& Bae, Jong-In, supra note 1, at 139; Kazuo, Hori, "Japan's Incorporation of Takeshima into Its Territory in 1905", 28 Korea Observer 485 (1997). 
In the seventeenth century, a Korean fisherman named An Yong-bok had direct talks with a branch of Japanese government and was given explicit recognition that the Liancourt Rocks belonged to the Cho-sun Dynasty (Korea's predecessor). ${ }^{9}$ Opinions differ between Korea and Japan on the credibility of the historic record and the status of An as an official representative of the Chosun Dynasty. Japanese scholars challenge the authenticity of An's statements on the grounds that they were made during interrogation by the Bi-byon-sa (Border Defense Council) because he gave color to the truth fearing criminal punishment for traveling abroad without government permission. ${ }^{10}$

\subsubsection{The Japanese 'Civilization'}

Japan adopted a aloofness policy against western nations ${ }^{11}$ until it was jolted by America in 1854 and humiliated by concluding unequal treaties with western nations. ${ }^{12}$ Afterwards Japan tried to terminate the unequal treaties by becoming civilized, Europeanized or westernized ${ }^{13}$ and learning rules of European international law. ${ }^{14}$ Japan then practiced European policies of colonialism and expansion in their relations with their neighbors in East Asia, applying European international law to its greatest strategic advantage. ${ }^{15}$

\subsubsection{Imperial Ordinance No. 41 of the Korean Empire}

The Korean government promulgated Imperial Ordinance No. 41 on October 25, 1900. Article 2 of the Ordinance had the basic purpose of restructuring the administrative district of Ullungdo by setting up a new county unit, expressly designating the county to administer the territory of the Liancourt Rocks. ${ }^{16}$ An inspector was dispatched by the Korean government to the Ullung

9 For a detailed overview of this incident, see Park, Hee Kwon \& Bae, Jong In, supra note 1, at $140-43$.

10 Taijudo, Kanae, "The Dispute between Japan and Korea with Respect to Sovereignty over Takeshima", The Japanese Annual of International Law (1968) No. 12, at 5; reprinted in Park, Hee Kwon \& Bae, Jong In, supra note 1, at 143.

11 See Anand, R. P., Studies in International Law and History: An Asian Perspective 95-96 (2004).

12 See Ibid., at 96.

13 See Ibid., at 96.

14 See Ibid., at $96-97$.

15 See Ibid., at $97-98$.

16 Official Gazette, No. 1716, Oct. 27, 1900; reprinted in Park, Hee Kwon \& Bae, Jong In, supra note 1 , at 144 . 
area to obtain specific information on the Liancourt Rocks. Furthermore, Kim Ok-kyun was designated in charge of the islet, thereby clearly demonstrating sovereignty. ${ }^{17}$

The Japanese Incorporation Measure of 1905 with regard to the Liancourt Rocks

Japan annexed the Liancourt Rocks on February 22, 1905 (38th year of the Meiji era) by means of public notice 40 of Shimanken (Shimane perfecture) to the effect: “... The Island 85 miles northwest of Okinoshima shall be designated as Takeshima and be placed under the jurisdiction of the head of Okinoshima."18 At that time, the entire territory of Korea had become the focus of aggression by expansionist Japan and Korea was unable to focus attention on a distant, uninhabited island and was not in a position to lodge any protest against the Japanese action. ${ }^{19}$

The Korean central government, the local Ullungdo County Chief, and civilians all considered the Japanese incorporation of Takeshima/Dokdo as an act of aggression at that time. But, by that time, Japan had virtually instituted colonial rule over Korea, by establishing the Residency-General in Korea. Consequently, no further development could be made within the Korean government to cope with the problem of the Liancourt Rocks. Because the entire country was being robbed of its vanishing sovereignty, the problem of the ownership of a small rocky island was put aside. However, the fact that the Korean people clearly raised objection to the Japanese action of incorporating the Liancourt Rocks within its best capability, is a decisively important factor worthy of historical evaluation. ${ }^{20}$

However, by incorporating the Liancourt Rocks in 1905, Korea's original title is alleged to have been replaced by Japanese title recognized in positive international law, ${ }^{21}$ even though, at first glance, Korea's historic title is considered relatively more convincing than that of Japan. Japan emphasizes the ruling in the Minquiers and Ecrehos (Fr. v. U.K.) that "[A]n alleged original title must have lapsed as a consequence of the events of the following years. It could

17 Park, Hee Kwon \& Bae, Jong In, supra note 1, at 144.

18 Kawakami Kenzo, Takeshima no rekishi Chirigakuteki Kinkyu (Historical and Geographical Study of Takeshima) (Tokyo: Kinkoshoten, 1966), at 212; reprinted in Lee, Han Key, supra note 5 , at 1 .

19 Lee, Han Key, supra note 5 , at 2.

20 Kazuo, Hori, supra note 8, at 524.

21 Lee, Han Key, supra note 5, at 62, note 108. 
today produce no legal effect, unless it had been replaced by another title valid according to the law of the time of replacement."22

\subsubsection{Japanese Imperial Expansion into Korea and Asian Nations}

Strategically situated and rich in natural resources, Korea was an important cornerstone of the Japanese imperial structure. Recognizing an advantage in employing international law in Korea, Japan modeled the "unequal treaty" it imposed on Korea after the "unequal treaty" which the West had imposed on Japan and which it bitterly denounced. On February 26,1876 , a treaty of amity, friendship, commerce and navigation was signed. There Korea opened three ports to Japanese ships and granted extraterritorial rights to Japanese citizens in Korea.

Learning the art of domination and colonization from the Western "civilized" States, ${ }^{23}$ Japan surpassed them all in suppressing its unfortunate neighbors which came under its sway. ${ }^{24}$ The Japanese Government and publicists sought to justify these actions on the basis of international law.

In the beginning, Japan accepted European international law not because it was committed to the values and philosophy underlying this law, but because it was too weak to challenge the Western powers. But the Japanese realized soon enough the truth about the abuse of international law by strong nations. Once Japan became a great power and found Western international law limiting its ambitions, it did not hesitate to use force to change it and violated international with impunity. ${ }^{25}$ As Japan experienced economic problems and the country increasingly needed ways to expand its exports and secure its imports of raw materials with the empire expanding, the military came to the fore. ${ }^{26}$ In August 1945, Japan was the first victim of two atomic bombs that brought untold suffering to Japan at a time when it was already on the verge of collapse. Japan could not continue the war after this devastation, and had no choice but to surrender. ${ }^{27}$

22 Minquiers and Ecrehos (Fr. v. U.K.), 1953 ICJ 12 (Oct. 16) [hereinafter referred to as "Minquiers and Ecrehos (Fr. v. U.K.)"], at 56 (slightly altered by an author).

23 Peattie, Mark R., "The Japanese Colonial Empire, 1895-1945", The Cambridge History of Japan, Vol. 6, The Twentieth Century 238 (Peter Duus (ed.), 1989); reprinted in Anand, supra note 11 , at 63 .

24 See Peattie, supra note 23, at 244-270; reprinted in Anand, supra note 11, at 63 .

25 Onuma Yasuki, “Japanese International Law' in the Prewar Period - Perspective on the Teaching and Research of International Law in Prewar Japan", Japanese Annual of International Law, No. 29 (1986), at 41; reprinted in Anand, supra note 11, at 63-64.

26 Anand, supra note 11, at 64.

27 Ibid., at 100. 
2.1.9 Post-War Disposition of Japan's Territory

The basic principle of the Allied Powers concerning the disposition of Japan's territory was that those territories which were illegally seized by Japan revert to their original owners. The post-war disposition of Japanese territory by the Allied Powers was based on a series of international instruments ranging from the Cairo Declaration to the Peace Treaty between the Allied Powers and Japan. The Cairo Declaration of November 27, 1943, stated that “... Japan shall be stripped of all the islands in the Pacific which she has seized or occupied since the beginning of the First World War and that Japan will also be expelled from all other territories which she has taken by violence and greed."28 The subsequent Potsdam Declaration endorsed the Cairo Declaration by stating that "The terms of the Cairo Declaration shall be carried out and Japanese sovereignty shall be limited to the Islands of Honshu, Hokkaido, Kyushu, Shikoku, and such minor Islands as we determine."29 Japan accepted the Potsdam Declaration on September 2, 1945, thus, becoming legally bound to both Declarations. Concomitantly, Japan also recognized, by the Peace Treaty, the independence of Korea, and solemnly pledged to the Allied Powers to return all inherent Korea to the Republic of Korea.

The United States Initial Post-Surrender Policy for Japan dated September 6, 1945, provides that "Japan's sovereignty will be limited to the islands of Honshu, Hokkaido, Kyushu, Shikoku and such minor outlying islands as may be determined, in accordance with the Cairo Declaration and other agreements to which the United States is or may be a party." Subsequent to the Post-Surrender Policy, the Supreme Commander for the Allied Powers' Directive (SCAPIN No. 677) dated January 29, 1947, clearly provided that the Liancourt Rocks is excluded from Japanese territory according to the following terms:

1. The Imperial Japanese Government is directed to cease exercising, or attempting to exercise, governmental or administrative authority over any area outside of Japan, or over any governmental officials and employees or any other persons within such areas.

28 It also states that "The aforesaid three Powers (USA, Great Britain, and China), mindful of the enslavement of the people of Korea, are determined that in due course Korea shall become free and independent." United States, Department of State Bulletin, Vol. IX (Washington D.C.; U.S. Government Printing Office, 1943), at 393; reprinted in Park, Hee Kwon \& Bae, Jong In, supra note 1 , at $157-58$.

29 United States Congress, Senate Committee on Foreign Relations, A Decade of American Policy: Basic Documents, 1941-1949 (Washington D.C.; U.S. Government Printing Office, 1950), at 5o; reprinted in Park, Hee Kwon \& Bae, Jong In, supra note 1, at 158. 
3. For the purpose of this directive, Japan is defined to include: the four main islands of Japan (Hokkaido, Honshu, Kyushu and Shikoku) and the approximately 1,0oo smaller adjacent islands, including the Tsuhima Islands...; excluding Utsuryo (Ullung) Island, the Liancourt Rocks (Take Island) and Quelpart (Saishu or Cheju) Island ... ------

5. The definition of Japan contained in the directive shall also apply to all future directives, memoranda and orders from this Headquarters unless otherwise specified therein.

Korea emphasizes that even the Japanese Government scrupulously followed the terms of SCAPIN No. 677 and issued some domestic legislation defining "Dokdo" (as Korea called the island), not "Takeshima" or "the Liancourt Rocks" as part of the foreign territories.

On the other hand, the Japanese government cites Paragraph 5 of the same Directive, which reads that "Nothing in this directive shall be construed as an indication of Allied policy relating to the ultimate determination of the minor islands referred to in Article 8 of the Potsdam Declaration," in response to the express reversion of the Liancourt Rocks to Korea. Additionally, the San Francisco Peace Treaty did not mention the Liancourt Rocks as one of the islands expressly excluded from Japan's territory. Article 2 of the Peace Treaty simply states that "Japan recognizing the independence of Korea, renounces all right, title and claim to Korea, including the Islands of Quelpart, Port Hamilton and Dagelet."30 The Japanese argue that the absence of any reference to the Liancourt Rocks in the Peace Treaty implies that the Liancourt Rocks territory belongs to Japan.

\subsubsection{Korea's Occupation of the Liancourt Rocks}

The Korean government did not haphazardly leave the island to itself when it was independent from Japanese imperialist rule. ${ }^{31}$ Before the conclusion of the San Francisco Peace Treaty, Korea exercised its sovereign authority over the Liancourt Rocks as the Republic of Korea was founded in August 1948.

On January 18, 1952, Korea promulgated the Presidential Declaration concerning its sovereignty over the contiguous sea, commonly called the Peace Line or Rhee Line. This action officially became a turning point, triggering a diplomatic row between the two countries over the title to the Liancourt

$30 \quad$ Park, Hee Kwon \& Bae, Jong In, supra note 1, at 158-60.

31 Kajimura, Hideki, “The Question of Takeshima/Tokdo", 28 Korea Observer 423, 463 (1997). 
Rocks. ${ }^{32}$ The Japanese action was prompted by the belief that the "adjacent seas" included the Liancourt Rocks. In the official protest, the Japanese government stated:

"The Republic of Korea appears to assume territorial rights over the islets in the Sea of Japan known as Takeshima or Liancourt Island, but Japanese government does not recognize such assumption or demand by the Republic of Korea ..." ${ }^{33}$ In response, the Korean delegation in Tokyo countered in a memorandum dated February 12 of that year; again this was confuted by the Japanese government by a memorandum dated April $25 \cdot{ }^{34}$

\subsubsection{Basic Treaty for the Restoration of Korean-Japanese Relations}

On June 22, 1965, a basic treaty for the restoration of Korean-Japanese relations and other agreements were signed, thus putting an end to the Korean-Japanese negotiations that had dragged on for 14 years. But, in the process of the tierebuilding talks between the two countries the territorial issue of the Liancourt Rocks never was discussed as an item on the agenda, for both wholly understood the issue would run as a large obstacle to rebuilding relations.

However, in the "instruments exchanged for peaceful settlement of disputes," both parties agreed to settle a dispute first through diplomatic channels unless otherwise agreed upon and to resort to arbitration according to the procedures to be agreed on by the two parties if settlement of a dispute failed through diplomatic channels. The problem is whether the issue of the Liancourt Rocks corresponds to the 'dispute' that is supposed to be settled firstly diplomatically and then judicially. The Japanese government asserts that, although no mention was made of the Liancourt Rocks, the provision was apparently meant for the Liancourt Rocks. Therefore, Japan insists that the territorial question concerning the Liancourt Rocks should be settled by the method provided in the instruments exchanged. Contrary to this, the Korean government regards the Japanese view, as stretched-out interpretation in its favor because the question concerning the Liancourt Rocks territory was too big to be dealt with in such as generalized terms. ${ }^{35}$ Thus, a dispute settlement instrument in the

32 Lee, Hoon, "Dispute over Territorial Ownership of Tokdo in the Late Choson Period", 28 Korea Observer 389, 389 (1997).

33 Ministry of Foreign Affairs (MFA) Political Affairs Bureau, Dokdo yongyu kwon e kwanhan han'ilgan wangbok munso (Notes exchanged between Korea and Japan on Dokdo) (Seoul: MFA, 1956), at 4-5; reprinted in Lee, Han Key, supra note 5, at 2.

34 Lee, Han Key, supra note 5 , at 2.

35 Ibid., at 3 . 
'basic treaty' caused some degree of disagreement as to referring the territorial matter to a judicial body between the two states. In other words, it shifted the territorial question to another level of interpreting the actual scope of the consent to deferring to a judicial body rather than contributed to a comprehensive final settlement based on past colonial history.

\subsection{Observations on the Korean Claim to the Liancourt Rocks}

The Korean government claims that Korea's predecessor (Shil-la) had discovered the Liancourt Rocks (Koreans named it as Tok-do and the Japanese named it as Takeshima); subsequently, Korea dominated the territory effectively and continuously. According to the Korean claim, documentary evidence verifies that the Liancourt Rocks was regarded as an associated island of or a neighboring island of Ullungdo. Further, considering the primitive fishing techniques of the past, it was impossible to effectively manage the island of the Liancourt Rocks unless residents based their living on the nearby island of Ullungdo. ${ }^{36}$

Although the Government of the Cho-sun Dynasty enforced the policy of uninhabited island for the purposes of safety and security, it is asserted to be an exercise of state authority so that it should not be construed as the abandonment of the territory. ${ }^{37}$ Koreans therefore conclude that Korea's predecessors and the present Korean government have exercised effective and continuous control over the island since time immemorial. According to Japanese allegations, Japanese fishermen entered the island for economic reasons during the period in which the policy of vacant island was enforced. However, the government of the Cho-son Dynasty (predecessor of the Republic of Korea) officially and immediately protested to the Japanese government the trespass of Japanese fishermen, whenever it discovered them. Furthermore, Japan acknowledged that the Liancourt Rocks belonged to Korea. For example, during the shogunate period of Japan corresponding to the period of the Chosun Dynasty, Japanese voyages to the Liancourt Rocks were prohibited because Japan recognized that it was a foreign land. In the period of the Japanese early expansionist attempt to open Korean ports, there was an internal decision in the Japanese Government that Japan had no territorial rights to the Liancourt Rocks. ${ }^{38}$

Nevertheless, Korea has difficulty in proving dominion over the Liancourt Rocks with regard to the three following points. Firstly, it was Japan that

36 Hyun, Myung Chul, "The Japanese Perception of Tokdo During the Opening of Ports", 29 Korea Observer 93, 114 (1998).

37 See Lee, Han Key, supra note 5, at 53 .

38 Hyun, Myung Chul, supra note 36, at 114. 
actually occupied and administered the Liancourt Rocks since 1905 during the period of Japanese imperialism over Korea. ${ }^{39}$ Secondly, the Liancourt Rocks is not explicitly mentioned in the San Francisco Peace Treaty as an area to revert to Korean rule. Therefore, it may be possible to interpret the treaty to Korea's disadvantage. In other words, the Japanese allegation that the Allied Forces recognized Japan's claim to the Liancourt Rocks and thus Japan was never subject to the legal obligation to renounce control over the Liancourt Rocks, is not beyond the scope of interpretation..$^{40}$ Thirdly, Korea proposed listing the Liancourt Rocks into the territorial provision of the San Francisco Peace Treaty, but the U.S.A., the principal party of the Treaty, did not accept the suggestion. ${ }^{41}$

39 "As regards the island of Dokdo, otherwise known as Takeshima or the Liancourt Rocks, this normally uninhabited rock formation was according to our information never treated as part of Korea and, since about 1905, has been under the jurisdiction of the Oki Islands Branch Office of Shimane Prefecture of Japan." (1951/8/9 [USNARA/694.001/8-1051 CS/H], US Department of State, "A Letter to You Chan Yang from Dean Rusk," reprinted in "Documents concerning the Tokdo (the Liancourt Rocks) in the National Archives of the U.S.A.", reprinted in Lee, Seok-Woo ed., 9 Seoul International Law Journal 141, 187 (Spring 2002) [hereinafter referred to as "Liancourt Rocks' Document"]. "Both the Korean and Japanese Governments have published statements supporting their respective claims to Dokdo. A superficial reading would indicate that, independently of the question of the effect of the peace treaty, the Japanese have probably made out the better case." (1954/8/26 [USNara/Doc. No.: N/A], US Department of State, "Draft by Miss Fite: Conflicting Korean Japanese Claims to Doko Islands (Otherwise Known as Takeshima or the Liancourt Rocks)," reprinted in Liancourt Rocks' Document, ibid., at 210-11.

40 Hyun, Myung, Chul, supra note 36, at 95.

41 "With respect to the request of the Korean Government that -, the United States Government regrets that it is unable to concur in this proposed amendment." (1951/8/9 [USNARA/694.001/8-1051 CS/H]; reprinted in Liancourt Rocks' Document, supra note 39. "IV. Amendments Proposed by Korea; The Korean Government has proposed the following revisions in the July 3 draft: 1 . Revision of Article 2(a) to provide that Japan 'confirms that it renounced on August 9, 1945, all right, title and claim to Korea and the islands which were part of Korea prior to its annexation by Japan, including the islands Quelpart, Port Hamilton, Dagelet, Dokdo and Parando.' “(1951/5/29 [USNARA/694.001/5-2951 CS/ JEC], US Department of State, "Office Memorandum to Mr. Dulles from Mr. Allison: Unresolved Treaty Provisions", reprinted in Liancourt Rocks' Document, supra note 39, at 181-82)). See also 1948/9/16 [USNARA/894.014/9-1648 CS/v], The Foreign Service of the United States of America, United States Political Adviser for Japan, "Korean Petition concerning Sovereignty of 'Docksum', Ullung Do, Tsushima, and 'Parang' Islands", reprinted in Liancourt Rocks' Document, supra note 39, at 177-78; 1951/7/17 [USNARA/694.001/7-1751 $\mathrm{HH}$ ], US Department of State, "Incoming Telegram to Secretary of State", reprinted in Liancourt Rocks' Document, supra note 39, at 183-84; 1951/7/19 [USNARA/694.001/7-1951], US Department of State, "Memorandum of Conversation: Japanese Peace Treaty", reprinted in Liancourt Rocks' Document, supra note 39, at 184-85; 1952/11/5 [USNARA/ Doc. No.: N/A], US Department of State, "A Letter from Mr. Kenneth T. Young, Jr. (Director, 
However, immediately upon securing its independence of Japan, Korea effectively and continuously exercised administrative and judicial rights over the Liancourt Rocks. ${ }^{42}$ Currently, the basic stand of the Korean government is that the Liancourt Rocks is part of Korea's territory, and cannot be the subject of diplomatic negotiation. ${ }^{43}$ The Korean government emphasizes that the Liancourt Rocks should not be recognized as one of the undetermined parts of the world, and therefore Korea's position is that Korea should avoid creating unnecessary diplomatic struggles with Japan in order to consolidate Korea's dominion over the Liancourt Rocks. ${ }^{44}$ Consequently, the Korean government does not regard the issue as dispute and considers it a fait accompli that the island is its inherent territory beyond doubt. ${ }^{45}$

\subsection{Observations on the Japanese Claim to the Liancourt Rocks}

Japan asserted that Cho-sun Dynasty's policy of inhabited island amounted to territorial abandonment. According to the Japanese viewpoint, when Korea permanently abandoned the uninhabited territory in the Cho-sun Dynasty, it thereby lost sovereignty over it and the territory became terra nullius until Japan effectively occupied it later. ${ }^{46}$ Since that time, the Japanese government has permitted fishing activities near the Liancourt Rocks, and has effectively and continuously controlled it. In 1905, Japan gave internal notice of incorporating the Liancourt Rocks into Japan's District. Japan claims that its incorporation of the Liancourt Rocks or the public notice by the Shimane prefecture confirmed the intention of Japan to own the island and to incorporate it into the modern administrative system of Japan. ${ }^{47}$ While Korea claims that the incorporation occurred during the period when Japan aggressively deprived Korea of diplomatic rights and its sovereignty, Japan contends Korea could have protested against the "incorporation" of the Liancourt Rocks. Because

Office of Northwest Asian Affairs) to US Embassy in Korea”, reprinted in Liancourt Rocks' Document, supra note 39, at 195.

Sibbet, Benjamin K., "Tokdo or Takeshima? The Territorial Dispute between Japan and the Republic of Korea", 21 FDMILJ 1606, 1636-45 (1998); Lee, Han Key, supra note 5, at 9o, note 176.

Ministry of Foreign Affairs, Republic of Korea, The Government's Basic Position, available at http://dokdo.mofa.go.kr/eng/dokdo/government_position.jsp (last visited on February 6, 2019).

44 Ibid.

45 Lee, Han Key, supra note 5, at 9o, note 176.

46 See Encyclopedia of Public International Law (Bernhardt (ed.), 1992) [hereinafter referred to as "EPIL"], Vol. IV, at 830.

Lee, Han Key, supra note 5 , at 59. 
the Liancourt Rocks was incorporated at the time of Japan's colonization of Korea, before, during and after the Sino-Japanese War and the Russo-Japanese War, Korea asserts that this timing places the Liancourt Rocks into the category of "all other territories Japan had taken by violence and greed" in the Cairo Declaration. ${ }^{48}$

After the Second World War, the Liancourt Rocks was not specifically listed in the San Francisco Peace Treaty as an island that Japan was required to renounce. Currently, the official Japanese position is to strive toward a peaceful settlement with the Republic of Korea, while consistently asserting that the occupation of the Liancourt Rocks by the Republic of Korea is an illegal occupation undertaken with absolutely no basis whatsoever in international law. ${ }^{49}$ A the same time, Japan is very concerned about the current situation which has lasted more than half a century because the importance of a fait accompli is known to be very great in international relations and a fait accompli, even though it is the consequence of unlawful action, may not be overruled in the future, unlike that in domestic society. ${ }^{50}$

Relevant cases on land and boundary disputes will be analyzed. The question to be asked here is what processes 'the International Arbitral Tribunals [hereinafter referred to as "Tribunal"], the International Court of Justice [hereinafter referred to as "ICJ"], the Permanent Court of Arbitration [hereinafter referred to as "PCA"] and the Permanent Court of International Justice [hereinafter referred to as "PCIJ"]' (hereinafter all referred to as "the Tribunal and the Court") used to reach their final decisions. In the opinion of this author, a regular process termed as "three-staged judicial review" can be recognized in the analysis of reasoning in the formation of territorial decisions.

48 Ibid., at 59 .

49 For a detailed discussion of Japan's Consistent Position, see The Ministry of Foreign Affairs of Japan, An Outline of the Japanese Position on Sovereignty over Takeshima and the Illegal Occupation by the Republic of Korea, available at https://www.mofa.go.jp/ region/asia-paci/takeshima/position.html (last visited on February 6, 2019).

5o Eito Shinkichi, Mukono tami to seiji (Innocent people and politics), at 282-83; reprinted in Lee, Han Key, supra note 5, at 90-91, note 176. 


\subsection{Palmas Island (U.S. v. Neth.)}

In Palmas Island (U.S. v. Neth.), ${ }^{51}$ the United States claimed that Spain originally discovered Palmas Island and subsequently ceded title to the United States under the Treaty of Paris. ${ }^{52}$ Conversely, the Netherlands claimed sovereignty based on their peaceful and continuous display of state authority over the island. ${ }^{53}$ The Arbitrator awarded Palmas Island to the Netherlands. ${ }^{54}$

The United States argued that Spain obtained an original title by discovery and that the effect of the act is to be determined by the law of the time when it was done. Accordingly, it was maintained that in the early period title based on discovery was of unquestioned validity. ${ }^{55}$ However, the arbitrator does not seem to have flatly committed himself on the nature of the rights formerly arising from discovery. ${ }^{56}$ The arbitrator Huber developed the theory of 'intertemporal law.' He said that 'a distinction must be made between the creation of rights and the existence of rights. The same principle which subjects the act creative of a right to the law in force at the time the right arises, demands that the existence of the right, in other words its continued manifestation, shall follow the conditions required by the evolution of law. 57 Therefore, the original sovereignty allegedly belonging to Spain by discovery ceased to exist by virtue of the principle of "inter-temporal law." On the other hand, the Netherlands proved that it displayed sovereignty continuously and peacefully on the island in question, completely replacing the title alleged to have belonged to Spain on the basis discovery or contiguity or historical data.

\subsection{Clipperton Island (Fr. v. Mex.)}

In Clipperton Island (Fr. v. Mex.), ${ }^{58}$ Mexico claimed that Spain originally discovered Clipperton Island and that Clippperton Island, therefore, belonged to Mexico as the successor of Spain. It would be necessary, to establish Mexico's claim to it, to prove that Spain not only had the right to incorporate the island in her possessions, but also had effective exercised the right before 1858 (as of

51 Island of Palmas Arbitration (U.S. v. Neth.), Arbitral Award of Apr. 4, 1928, 2 RIAA 829 (1928), reprinted in 22 Am. J. Int'l L. 867 (1928) [hereinafter referred to as "Palmas Island (U.S. v. Neth.)"].

$5^{2} \quad$ Ibid., at $835^{-36}$.

53 Ibid., at 857 .

54 Ibid., at 829 .

55 See Jessup, Philip C., "The Palmas Island Arbitration", 22 Am. J. Int'l L. 735, 737 (1928).

56 Ibid., at 738 .

57 Palmas Island (U.S. v. Neth.), at 883 .

$5^{8}$ Clipperton Island Arbitration (Fr. v. Mex.), 2 RIAA 1105 (1931), reprinted in Am. J. Int'l L. 390 (1932) [hereinafter referred to as "Clipperton Island (Fr. v. Mex.)"]. 
critical date). ${ }^{59}$ However, that has not been demonstrated at all. Mexico's claim based on an historic right is not supported by any manifestation of her sovereignty over the island. Conversely, the regularity of the act by which France made known, in clear and precise manner, her intention to consider the island as her territory, is incontestable. Therefore, the PCA held that the actions of the France ${ }^{60}$ were sufficient to establish sovereignty over the island and sovereignty over Clipperton Island belonged to France. ${ }^{61}$

\subsection{Eastern Greenland (Den. v. Nor.)}

In the dispute over Eastern Greenland, ${ }^{62}$ PCIJ stated that facts established Denmark's will and intention to act as sovereign and the display of such authority, and therefore, PCIJ held that Danish had title to sovereignty over Greenland resulting from a continuous and peaceful exercise of the authority of the States. It was also noted that engagements on the part of Norway was considered recognition of Danish sovereignty over Greenland, or an obligation not to dispute that sovereignty or not to occupy territory in Greenland. ${ }^{63}$ Accordingly, the PCIJ recognized Danish sovereignty over the whole of Greenland. ${ }^{64}$ In addition, this case demonstrated that a relatively slight exercise of authority would suffice when no state can show a superior claim. ${ }^{65}$

\subsection{Minquiers and Ecrehos (Fr. v. U.K.)}

In Minquiers and Ecrehos (Fr.v. U.K.), actual displays of authority and evidence of possession were of decisive importance in determining sovereignty issues. ${ }^{66}$ Although both claimants produced treaties and other historical documents in

59 Ibid., at 392-93; see EPIL, Vol. I, at 622.

6o As for the French sovereignty act, in particular, the taking of possession, the Tribunal said:

"It is beyond doubt that ... besides the anumus occupandi, the actual, and not nominal, taking of possession is a necessary condition of occupation. This taking of possession is a necessary condition of occupation. This taking of possession consists in the act or series of acts, by which the occupying State reduces to its possession the territory in question and takes steps to exercise exclusive authority there." EPIL, Vol. I, at 622.

61 Clipperton Island (Fr. v. Mex.), at 393-94.

62 Legal Status of Eastern Greenland Case (Den. v. Nor.), 1933 PCIJ (Ser. A/B) No. 53 (Apr. 5) [hereinafter referred to as "Eastern Greenland (Den. v. Nor.)"].

63 Eastern Greenland (Den. v. Nor.), at 22.

64 Eastern Greenland (Den. v. Nor.), at 48.

65 Eastern Greenland (Den. v. Nor.), at 50-51. See also Eritrea-Yemen Arbitration, Phase I: Territorial Sovereignty and Scope of Dispute (1998), available at http://www.pca-cpa.org/ ENGLISH/RPC/\#Eritrea (last visited on Oct. 17, 2005) [hereinafter referred to as "EritreaYemen Arbitration (Phase I: Territorial Sovereignty)"), paras. 452-523; Kasikili/Sedudu Island (Rezek, J., dissent). 
an attempt to prove that they possessed ancient or original title, ${ }^{67}$ the court found it unnecessary to resolve the historical controversies, ${ }^{68}$ and further held that what was of decisive importance was evidence which related directly to the possession of the islands and not indirect presumptions deduced from events that occurred in the Middle Ages. ${ }^{69}$ In other words, the ICJ pointed out that it was the relatively recent history of use and possession that ultimately proved to be decisive, although there was much argument about claims to very ancient titles. ${ }^{70}$

\subsection{Certain Frontier Land (Belg./Neth.)}

The Court was asked to settle a dispute as to sovereignty over two plots of land situated in an area where the Belgo-Cutch frontier presented certain unusual features. In that location, there had long existed a number of enclaves formed by the Belgian commune of Baerle-Duc and the Netherlands commune of BaarleNassau. A Communal Minute drawn up between 1836 and 1841 attributed the plots to Baarle-Nassau, whereas a Descriptive Minute and map annexed to the Boundary Convention of 1843 attributed them to Vaerle-Duc. The Netherlands maintained that the Boundary Convention recognized the existence of the status quo as determined by the Communal Minute, that the provision by which the two plots were attributed to Belgium ${ }^{71}$ was vitiated by an error, and that the sovereignty of the Netherlands over the disputed plots was established by the exercise of various acts of sovereignty dating from 1843 . After considering the evidence produced, the Court, in a Judgment delivered on June 20, 1959, determined that sovereignty over the two disputed plots belonged to Belgium. ${ }^{72}$

Under the Boundary Convention, sovereignty resided in Belgium. The question for the Court was whether Belgium lost its sovereignty by non-assertion of its rights and by acquiescence in acts of sovereignty alleged to have been

$67 \quad$ Ibid., at $53^{-}-57$.

68 Ibid., at 56.

$69 \quad$ Ibid., at 57. The tribunal in the Eritrea-Yemen Arbitration (Phase I: Territorial Sovereignty) adopted this reasoning, pointing out that although there was much argument about claims to very ancient titles it was the relatively recent history of use and possession that ultimately proved to be decisive. Eritrea-Yemen Arbitration (Phase I: Territorial Sovereignty), para. 450 .

70 Likewise, this reasoning was adopted by the tribunal in the Eritrea-Yemen Arbitration (Phase I: Territorial Sovereignty).

71 Sovereignty over Certain Frontier Land (Belg./Neth.), 1959 I.C.J. 209, 221 (June 20) [hereinafter "Certain Frontier Land (Belg./Neth.)"], at 222.

72 The summary of Sovereignty over Certain Frontier Land (Belgium/Netherlands) is available at https://www.icj-cij.org/files/case-related/38/4807.pdf (last visited on Feb. 1, 2019). 
exercised by the Netherlands at different times since $1843 \cdot^{73}$ The court found that Belgium had not ceased to assert its rights and that the encroachments of the Netherlands were insufficient to supplant Belgian sovereignty for two reasons. ${ }^{74}$ Firstly, the encroaching acts were "largely of a routine and administrative character performed by local officials and a consequence of the inclusion by the Netherlands of the disputed plots in its Survey." 75 Secondly, the plots were enclaves in the Netherlands, making it difficult for Belgium to detect these encroachments upon its sovereignty and exercise its own authority over the plots. ${ }^{76}$ The court thus awarded the territory to Belgium. ${ }^{77}$

\subsection{Temple of Preah Vihear (Cambodia v. Thai.)}

Cambodia brought action against Thailand for infringing on its territorial sovereignty over the land surrounding the ruins of the Temple of Preah Vihear. Thailand denied all violations of Cambodian sovereignty, claiming that the ruins were on its side of the common border ${ }^{78}$ The parties made claims based on treaties, effective control, history, geography, and culture. ${ }^{79}$ The dispute focused on a 1904 boundary treaty in which France and Siam (as Thailand was known at that time) established the border that later separated Cambodia and Thailand. ${ }^{80}$ The 1904 French-Siamese boundary treaty substantiated the Cambodian claim to sovereignty over the Temple land. ${ }^{81}$ That treaty, according to the Court, established the watershed line as the border but rested ultimate authority to draw the border with the Mixed Boundary Commission. ${ }^{82}$ In tandem with drawing the border, the commission had authority to map the entire region, which it delegated, with the consent of the Siamese commission representatives, to French officers. ${ }^{83}$ The French officers mapped the area and placed the Temple in French Indochina. ${ }^{84}$ Neither France nor Siam ever

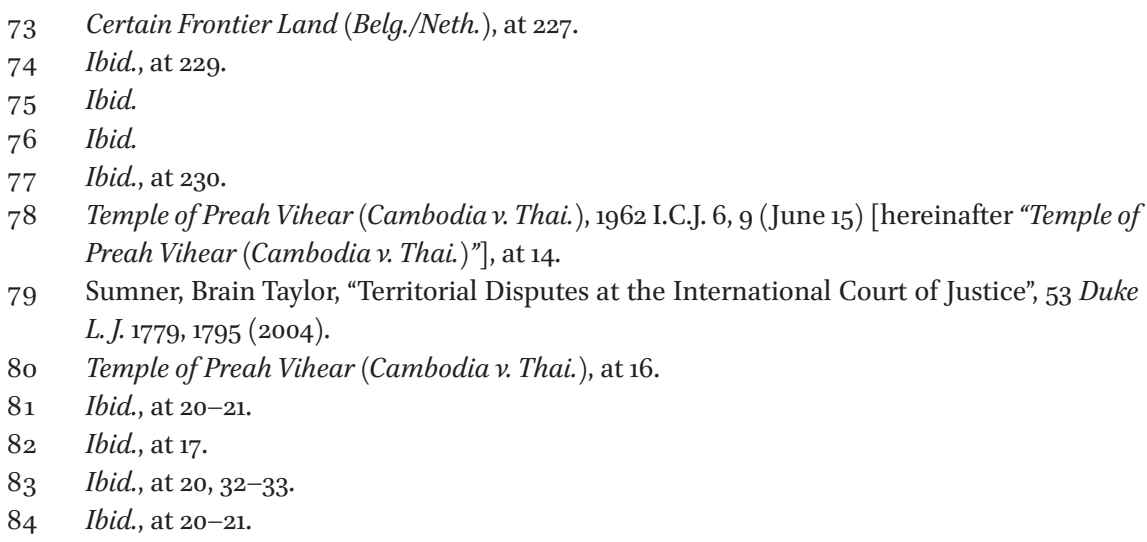


formally adopted these maps, but each country implicitly accepted them..$^{85}$ The implicit acceptance of maps showing the Temple in what became Cambodia substantiated Cambodia's claim against Thailand. ${ }^{86}$ The maps derived their importance from their mandate in the 1904 boundary treaty, and the borders that they reflected devolved to Cambodia and Thailand under uti possidetis. ${ }^{87}$

Along with that, the ICJ rejected Thailand's effective control claims by which it had asserted that acts subsequent to the 1904 treaty manifested its exercise of sovereignty. 88 Thailand's administrative acts were conducted by local authorities, were "very few [and] routine," and did not suffice to annul "the clear impression of acceptance of the frontier line at Preah Vihear." 89 When Siam openly protested the French (and later, the Cambodian) sovereignty in the disputed area, the latter replied through diplomatic channels, reaffirming its rights to engage Thailand in dialogue. ${ }^{90}$ The ICJ found this evidence of French and Cambodian jurisdiction to have continued over the Temple more convincing that that of Siamese jurisdiction. ${ }^{91}$ By relying on the maps produced by the 1904 boundary treaty, the court dismissed all other arguments as legally indecisive. ${ }^{92}$

\subsection{Frontier Dispute (Burk. Faso v. Mali)}

Burkina Faso based its sovereignty claim on the frontier delimited by the French colonial administration as shown in colonial maps. Mali, on the other hand, focused on the ethnicity of inhabitants and on legal documents attributing the region to the French Sudan (Mali's predecessor). ${ }^{93}$

In the case of Frontier Dispute (Burk. Faso v. Mali), the ICJ granted Burkina Faso the title of the disputed frontier, stressing that the principle of uti possidetis juris took the lead over effective possession as source of

\footnotetext{
85 Ibid., at 23 .

86 Sumner, supra note 79 , at 1796.

87 Ibid., at 1796.

88 Temple of Preah Vihear (Cambodia v. Thai.), at 27-29.

89 Ibid., at 30.

$90 \quad$ Sumner, supra note 79 , at 1796.

91 Temple of Preah Vihear (Cambodia v. Thai.), at 31-32.

92 Ibid., at 15.

93 On the background, see Allcock, John B., Border and Territorial Disputes 221-25 (3rd (ed.), 1992); Naldi, Gino J., "The case concerning the Frontier Dispute (Burkina Faso/Republic of Mali): Uti possidetis in an African perspective", 36 Int'l \& Comp. L. Q. 893, 893-94 (1987); Rosenne, Shabtai, The World Court - What it is and how it works 223-24 (5th (ed.), 1995); reprinted in Schulte, Constanze, Compliance with Decisions of the International Court of Justice 181-82 (2004).
} 
sovereignty. ${ }^{94}$ Further, the court considered the question concerning whether uti possidetis juris always trumps self-determination. In holding that uti possidetis juris takes priority over self-determination, the court expressly relied on a particular regional practice in Africa, according to which respect for boundaries existing at independence was seen as a necessity for realizing the practical benefits of self-determination; the court did not suggest that this decision of the conflict between two principles would necessarily apply in any other region. ${ }^{95}$ Although it does not appear to be well established that the principle of uti possidetis juris would always predominate over self-determination, the court held that "the principles of uti possidetis had kept its place among the most important legal principles." ${ }^{\text {96 }}$

\subsection{Land, Island and Maritime Frontier Dispute (El Sal. v. Hond.)}

In the case of Land, Island and Maritime Frontier Dispute (El Sal. v. Hond.), ${ }^{97}$ specifically in connection with the dispute over the islands located in the Gulf of Fonseca, Honduras contended that the only law applicable to the dispute was the principle of uti possidetis. El Salvador, on the other hand, maintained that the Chamber constituted by the ICJ for this case was bound to apply the modern law of acquisition of territory and consider the effective exercise of state control over the islands, as well as historical title. ${ }^{98}$ The Chamber held that the principle of uti possidetis should be adopted as a starting point in the determination of the sovereignty over the islands, since the issue involved

94 Frontier Dispute (Burk.Faso v. Mali) 1986 I.C.J. 545 [hereinafter referred to as "Frontier Dispute (Burk. Faso v. Mali)"], para. 23.

95 Ibid., para. 25 ("At first sight this principle of uti possidetis juris conflicts outright with another one, the right of peoples to self-determination. In fact, however, the maintenance of the territorial status quo in Africa is often seen as the wisest course, to preserve what has been achieved by peoples who have struggled for their independence, and to avoid a disruption which would deprive the continent of the gains achieved by much sacrifice. The essential requirement of stability in order to survive, to develop and gradually to consolidate their independence in all fields, has induced African States judiciously to consent to the respecting of colonial frontiers, and to take account of it in the interpretation of the principle of self-determination of peoples."). See also Hannum, Hurst, "Rethinking Self-determination", 34 Va. J. Int'l L. 1, 32 (1993); Frontier Dispute (Burk. Faso v. Mali), para. 26 ("Even though it does not appear to be well-established that the principle of uti possidetis juris would always predominate over self-determination, the court held that "the principles of uti possidetis had kept its place among the most important legal principles."). Frontier Dispute (Burk. Faso v. Mali), para. 26.

97 Case concerning the Land, Island and Maritime Frontier Dispute (El Sal. v. Hond.; Nicar. intervening), 1992 ICJ 351 (Sept. 11) [hereinafter referred to as "Land, Island and Maritime Frontier Dispute (El Sal. v. Hond.)"].

Ibid., at $361-71$. 
the right of succession of the newly independent states of Central America to the islands. ${ }^{99}$ The Chamber nonetheless encountered difficulties in attempting to apply this principle, as the sparse documents that might have testified to the membership of the islands to one administrative district or the other provided only an incomplete picture. ${ }^{100}$ As a result, the Chamber was obliged to focus more on the behavior of the parties with regard to the islands after independence was achieved in $1821 .{ }^{101}$ The Chamber considered that it might have resorted, only in limited cases lacking clear evidence of uti possidetis juris, to documentary evidence of post-independence effectivités affording indications of the 1821 utipossidetis juris boundary, provided a relationship existed between the effectivités and the determination of that boundary, ${ }^{102}$ while assuming that "the principle of uti possidetis juris accorded pre-eminence to legal title over effective possession as a basis of sovereignty"103 in Latin America. ${ }^{104}$

\subsection{Territorial Dispute (Libya/Chad $)^{105}$}

The dispute over the Aouzou Strip between Libya and Chad before the ICJ was conclusively determined by a Treaty to which Libya is an original party and Chad a party in succession to France. The ICJ's conclusion that the Treaty contains an agreed boundary renders it unnecessary to consider the history of the "Borderlands" claimed by Libya on the basis of title inherited from

$99 \quad$ Ibid., at $55^{8-59 .}$

100 EPIL, Vol. III, at 122; For further details of it, see the following:

In defining the borders of the six sectors in dispute, the Court also proceeded on the basis of the uti possidetis juris principle, according to which the national frontiers of former colonies correspond to the earlier administrative borders of the colonies. The Court explicitly indicated that it was the use of this principle which provided States liberated from former colonial empires with internationally recognized borders. Both El Salvador and Honduras had attempted to demonstrate to which of the former administrative unit each had succeeded. This proved to be difficult due to the absence of sufficient documents containing exact descriptions of the areas and administrative frontiers of that time. Furthermore the terms "territorial sovereignty" and "administrative unit" were not necessarily synonymous; besides the secular administrative units, there were also ecclesiastical districts. Thus the Court recognized only title deeds granted by the Spanish crown as valid proof of title. Finally, in its deliberations regarding the delimitation of the border, the Court took topographical characteristic into account in order to define a clearly recognizable border. EPIL, Vol. III., at 121 .

101 As for this point, see EPIL, Vol. III, at 122.

102 Land, Island and Maritime Frontier Dispute (El Sal. v. Hond.), at 399-400.

103 Frontier Dispute (Burk. Faso v. Mali), at 565.

104 See "International Decision: Land, Island and Maritime Frontier Dispute (El Sal. v. Hond.; Nicar. intervening), 1992 I.C.J. 351 (Sept. 11)", 87 Am. J. Int'l L. 618, 626 (1993).

105 Case Concerning the Territorial Dispute (Libya/Chad), 1994 ICJ 6 (Feb. 3) [hereinafter referred to as "Territorial Dispute (Libya/Chad)"], para. 73 . 
the indigenous people, the Senoussi Order, the Ottoman Empire and Italy. ${ }^{106}$ Concerning the foremost importance of a boundary treaty in settling territorial sovereignty, the Court stated:

A boundary established by treaty thus achieves a permanence which the treaty itself does not necessarily enjoy. The treaty can cease to be in force without in any way affecting the continuance of the boundary. In this instance the Parties have not exercised their option to terminate the Treaty, but whether or not the option be exercised, the boundary remains. This is not to say that two States may not by mutual agreement vary the border between them; such a result can of course be achieved by mutual consent, but when a boundary has been the subject of agreement, the continued existence of that boundary is not dependent upon the continuing life of the treaty under which the boundary is agreed ...107

Then, because the 1955 Treaty was clear on the boundary question, it was unnecessary for the ICJ to further consider uti possidetis, title inherited from indigenous peoples, ${ }^{108}$ or sphere of influence. ${ }^{109}$

\subsection{Eritrea-Yemen Arbitration (Phase I: Territorial Sovereignty)}

In the case of Eritrea-Yemen Arbitration (Phase I: Territorial Sovereignty), Eritrea claimed territorial sovereignty over all the islands by virtue of Italian sovereignty, which, it argued, was acquired by effective occupation sometime after Turkish renunciation. ${ }^{110}$ The Italian title was transferred allegedly to Ethiopia and, Eritrea succeeded to it when Eritrea seceded from Ethiopia in 1993. ${ }^{111}$ Conversely, Imam (Yemen's predecessor) was not a party to the Treaty

\footnotetext{
106 Ibid., para. 75 .

107 Ibid., para. 73 .

108 Territorial Dispute (Libya/Chad), at 12-13.

109 Ibid., at 38-40.

110 The Treaty of Lausanne's Article 16 provides that "Turkey hereby renounces all rights and title whatsoever over or respecting the territories situated outside the frontiers laid down in the present Treaty and the islands other than those over which her sovereignty is recognized by the said Treaty, the future of those territories and islands being settled or to be settled by the parties concerned.... Treaty of Peace, signed at Lausanne, Jul. 24, 1923, The British Empire, France, Italy, Japan, Greece, Romania, Serb-Croat-Slovene State and Turkey." 28 L.N.T.S. 12-13. Art. 16; reprinted in Eritrea-Yemen Arbitration (Phase I: Territorial Sovereignty), para. 157 .

111 Reisman, W. Michael, "International Decisions: Awards of the Arbitral Tribunal in the First Stage of the Proceedings (Territorial Sovereignty and Scope of the Dispute)", 93 Am. J. Int'l L. 668,669 (1999).
} 
of Lausanne and in that technical sense was the Treaty res inter alios acta to Yemen. ${ }^{112}$ As to Yemen's contention, the PCA held that "this special category of treaties represents a legal reality which necessarily impinges upon third states, because they have effect of erga onmes."113 The special category of treaties was a peace treaty in this case. Specifically, the PCA explained that "[i]f State A has title to territory and passes it to State B, then it is legally without purpose for State $\mathrm{C}$ to invoke the principle of res inter alios acta, unless its title is better than that of A (rather than of B). In the absence of such better title, a claim of res inter alios acta is without legal import."114 The PCA concluded that Yemen's claim could have no effect, as Yemen did not have title at the time when the Peace Treaty was concluded.115

Despite this "innovative presumption"116 with regard to the effect of a peace treaty on its non-party, however, "the Tribunal and the two parties before it could determine sovereignty only by reference to alleged effectivités of Eritrea and Yemen"17 because it read Article 16 as follows:

In 1923, Turkey renounced title to those islands over which it had retained sovereignty to that time. The islands did not become res nullius - that is to say, open to acquisitive prescription - by any state, including any of the High Contracting Parties (along with Italy). Neither did they automatically revert (insofar as they had even belonged) to the Imam [predecessor of Yemen]. Sovereign title over the islands remained indeterminate pro tempore. ${ }^{118}$

This negative analysis of Article 16 of the Treaty of Lausanne does not answer the question of who is the territorial sovereign of the contested islands, but

112 Eritrea-Yemen Arbitration (Phase I: Territorial Sovereignty), para. 153. The reason why Yemen claimed res inter alios acta effect of the Peace Treaty in question, is that the chainof-title for a reversion would have been interrupted because the Treaty of Lausanne could have validly alienated Ottoman Empire's title to the islands. Ibid., para. 125. According to Yemen's claim, Biladel Yemen was alleged to have an historic or ancient title running back in time to the middle ages, and then Ottoman Empire was alleged to occupy the territory in question in the nineteenth century. And at last the title was alleged to revert to modern Yemen after the collapse of the Ottoman Empire at the end of the First World War. See Ibid., para. 116-17.

113 Ibid., para. 162.

114 Ibid., para. 153 .

115 Ibid., para. 152.

116 Reisman, supra note 111 , at 678.

117 Ibid., at 671.

118 Eritrea-Yemen Arbitration (Phase I: Territorial Sovereignty), para. 165. 
rather establishes who the territorial sovereign was not and, therefore, who could not pass title to a putative successor. ${ }^{119}$ Holding that Article 16 of the Treaty of Lausanne was not decisive to the Tribunal in deciding which party had sovereignty over the disputed islands and neither party was able to establish historic title to them, the PCA reviewed the relatively recent history of use and possession (factual evidence of alleged "effectivités"), which proved decisive. ${ }^{120}$

Further, it is notable that the PCA did not accept the sovereignty over the islands in dispute to be returned to Yemen, ${ }^{121}$ dismissing the principle of reversion of territory to a former state. Yemen claimed the disputed islands principally on the basis of a theory of reversion, ${ }^{122}$ arguing that the islands were historically Yemeni from the sixth century. After the Ottoman Empire withdrew in 1923, the islands reverted back to their original owner (Yemen). ${ }^{123}$ The PCA rejected Yemen's argument for returning a title to it. ${ }^{24}$ By fact, it held that Yemen was not able to establish historic title to the islands, islets and rocks. ${ }^{125}$ By law, the PCA even declared that the doctrine of reversion of territorial title is unproven in international law, ${ }^{126}$ denying "title passing automatically by reversion from Turkey to Yemen."127

\subsection{Kasikili/Sedudu Island (Bots. v. Namib.)}

The special agreement between the Government of the Republic of Botswana and the Government of the Republic of Namibia asked the ICJ "to determine, on the basis of the Anglo-German Treaty of 1 July 1890 and the rules and principles of international law, the boundary between Namibia and Botswana around Kasikili/Sedudu Island and the legal status of the island." ${ }^{28}$ In its judgment of December 13, 1999, the ICJ determined by 11 votes to 4 that the boundary between Botswana and Namibia followed the line of the deepest soundings in the northern channel of the Chobe River around Kasikili/Sedudu Island and

\footnotetext{
119 Reisman, supra note 111, at 671.

120 Eritrea-Yemen Arbitration (Phase I: Territorial Sovereignty), paras. 239-361.

121 Ibid., para. 148.

122 Ibid., paras. 331-34

123 Ibid.

124 Ibid., para. 125 .

125 Ibid., para. 449 ("It had not persuaded the Tribunal that the historic bilad el Yemen had exercised territorial control over coastal areas and perforce over the islands."). See Reisman, supra note 111, at 670 .

126 Eritrea-Yemen Arbitration (Phase I: Territorial Sovereignty), para. 125.

127 Ibid., para. 151.

128 Kasikili/Sedudu Island (Bots./Namib.) (Special Agreement), available at https://www.icj -cij.org/files/case-related/98/7185.pdf (last visited on Jan. 31, 2019), Article I.
} 
that the island formed part of the territory of Botswana, and unanimously, that nationals and vessels flying the flag of Botswana and Namibia were entitled to "equal national treatment" in the two channels around the island. ${ }^{129}$

The parties agreed that the ICJ was to deliver its decision on the basis of the 1890 Treaty, which they recognized as applicable and binding. However, it was controversial whether the special agreement asked the ICJ to declare that it had sovereignty over Kasikil/Sedudu Island based on prescription as well as the Anglo-German treaty, as Namibia claimed. Botswana's position was that under the special agreement, the ICJ was only asked to determine the boundary under the 1890 treaty and prescription could therefore play no role. ${ }^{130}$

The ICJ held that it was not only authorized to interpret the treaty in the light of the rules and principles of international law, but that it was also asked to apply those rules and principles independently. Hence, after the ICJ decided on the definition of the boundary under the treaty, it proceeded to consider the question of prescription. ${ }^{131}$ However, the ICJ held that Namibia itself had not fulfilled the conditions that it cited as necessary for the acquisition of territory through prescription. ${ }^{132}$ On the basis of its findings on the boundary pursuant to the 1890 treaty and its rejection of Namibia's claims relating to prescription, the ICJ reached the conclusion that the island of Kasikili/Sedudu belonged to Botswana. ${ }^{133}$

Contrary to the majority's conclusion, Judge Kooijmans criticized, in his separate opinion, the ICJ's review of Namibia's alternative claim that it had title to Kasikili/Sedudu on the basis of the doctrine of acquisitive prescription after having found that in accordance with the terms of the 1890 Treaty the boundary was in the northern channel, stating that "this part of Namibia's claims should have been declared inadmissible" and casting one fundamental question; "if Namibia had been able to prove that the requirements for acquisitive prescription had been fulfilled, would the court have been expected to use it to the question concerning the legal status of the Island in order to trump the finding on the basis of the terms of the 1890 Treaty?"134

129 Case concerning Kasikili/Sedudu Island (Bots. v. Namib.) (1999), available at https://www .icj-cij.org/files/case-related/98/og8-19991213-JUD-01-oo-EN.pdf (last visited on Jan. 31, 2019) [hereinafter referred to as "Kasikili/Sedudu Island (Bots. v. Namib.)"], para. 104. For details of the judgment, see Evans, Malcolm, "Case concerning Kasikili/Sedudu Island", 49 Int'l \& Comp. L. Q. 964 (200o); Perry, Alan, "Caprivi Strip: World Court awards island to Botswana", 8 IBRU International Boundary and Security Bulletin 8o (2000).

130 Kasikili/Sedudu Island (Bots. v. Namib.), at 1101, para. 91.

131 Ibid., para. 93. See also Evans, supra note 129, at 965-67.

132 Kasikili/Sedudu Island (Bots. v. Namib.), paras. 90-99.

133 Ibid., para. 100-101.

134 Kasikili/Sedudu Island (Bots. v. Namib.) (Kooijmans, J., separate), para. 19. 


\subsection{Territorial Questions (Qatar v. Bahr.)}

In the case of Territorial Questions (Qatar v. Bahr.), ${ }^{135}$ the ICJ dealt with the question of sovereignty over the Hawar islands. While Bahrain claimed title to the Hawar islands on the basis of a British decision of July 11, 1939, Qatar founded its claim on proximity and a prior title. ${ }^{136}$ Of the six legal grounds on which the parties argued that sovereignty over the Hawar islands might be based, the ICJ dealt only with the decision made by the British government on July 11, 1939. The ICJ considered that a third-party decision to award the Hawar islands to Bahrain was regarded as binding, ${ }^{137}$ though the 1939 decision did not lead to an international arbitral award that would have had force of res judicata, ${ }^{138}$ because it was expected "to be rendered 'in the light of truth and justice.'139 It was proven from the following facts; the 1938-39 Exchange of Letters showed that Bahrain and Qatar had consented to the British Government settling their dispute over the Hawar islands; ${ }^{140}$ the process had been fair, ${ }^{141}$ and the parties had a fair opportunity. ${ }^{142}$ This legal finding, the ICJ stated, rendered it unnecessary for it to rule on the other arguments such as the applicability of the principle of uti possidetis juris to the present case, or the existence of an original title and effectivités. ${ }^{143}$

\subsection{Land Boundary (Cameroon v. Nig.)}

In the case of Land Boundary (Cameroon v. Nig.), ${ }^{144}$ admitting the validity of certain colonial arrangements (Thompson-Marchand Declaration,

135 Case concerning Maritime Delimitation and Territorial Questions between Qatar and Bahrain (Qatar v. Bahrain) (2001), available at https://www.icj-cij.org/files/case-related/ 87/087-19940701-JUD-01-0o-EN.pdf (last visited on Jan. 31, 2019) [hereinafter referred to as "Territorial Questions (Qatarv. Bahr.)"].

136 Ibid., paras. 99-109.

137 Ibid., paras. $111-47$.

${ }_{13} 8$ The Court found the award lacked the necessary formal and procedural preconditions to be arbitration, namely, a process for "the settlement of differences between States by judges of their own choice, and on the basis of respect for law." Ibid., para. 112-14. However, the Court stated that "the fact that a decision is not an arbitral award does not mean that the decision is devoid of legal effect." Ibid., para. 117 .

139 Ibid., para. 140

140 Ibid., paras. $137 \& 139$.

141 Ibid., paras. 141 \& 143.

142 Ibid., para. 142.

143 Ibid., paras. $110 \& 148$.

144 Land and Maritime Boundary Between Cameroon and Nigeria (Cameroon v. Nig.; Eq. Guinea intervening), I.C.J., Judgment (Oct. 10, 2002), available at https://www.icj-cij.org/ files/case-related/94/o94-19980611-JUD-01-0o-EN.pdf (last visited on Jan. 31, 2019) [hereinafter referred to as "Land Boundary (Cameroon v. Nig.)"], para. 325. 
Henderson-Fleurian Exchange of Notes; British Order in Council, 1946; AngloGerman Agreements of 11 March and 12 April 1913) and holding that the ICJ's task was not to delimit the boundary de novo nor to demarcate it, but to "specify definitively" the course of the boundary as fixed by the relevant instruments, ${ }^{145}$ the ICJ ruled that "the dispute between Cameroon and Nigeria over certain points on the land boundary between Lake Chad and Bakassi is, in reality, simply a dispute over the interpretation or application of particular provisions of the instruments delimiting that boundary."146 While the ICJ addressed Nigeria's claim to title to the disputed Lake Chad area based on historical consolidation of title (presence) and Cameroon's acquiescence or tacit consent, ${ }^{147}$ it regarded historical consolidation and effective control at present as incapable of replacing the established modes of acquisition of title to territory under international law. ${ }^{148}$ The ICJ held that nothing in case law suggested that historical consolidation and land occupation was allowed to set aside an established conventional territorial title. ${ }^{149}$ Regarding the legal relationship between effectivités and titles, the ICJ recalled its earlier findings that preference should be given to the holder of the title over another state administering a disputed territory. ${ }^{150}$

\subsection{Pulau Ligitan and Sipadan (Indon./Malay.)}

In the case of Pulau Ligitan and Sipadan (Indon./Malay.), ${ }^{151}$ the ICJ first reviewed Indonesia's principal argument to the effect that it held a treatybased title on the grounds of the 1891 Convention between Great Britain and the Netherlands. Article IV of the treaty provides, in part, "From $4^{\circ} 10^{\prime \prime}$ north latitude on the east coast the boundary-line shall be continued eastward along that parallel, across the Island of Sebatik."152 The question presented was whether this wording was referred to as a line that continued indefinitely eastward so as to serve as a line of allocation attributing sovereignty to disputed islands, or whether the line just stopped on the east coast of Sebatik so as not

\footnotetext{
145 Ibid., paras. 41-55.

146 Ibid., para. 85 .

147 Ibid., para. 62.

148 Ibid., para. 65.

149 Caron, David D. et al, "International Decision: Land and Maritime Boundary between Cameroon and Nigeria", 97 Am. J. Int'l L. 387, 389 (2003).

150 Land Boundary (Cameroon v. Nig.), para. 68 (with reference to Frontier Dispute (Burk. Faso v. Mali), para. 63).

151 Sovereignty over Pulau Ligitan and Pulau Sipadan (Indon./Malay.), available at https:// www.icj-cij.org/files/case-related/102/102-20011023-JUD-01-00-EN.pdf (last visited on Jan. 31, 2019) [hereinafter referred to as "Pulau Ligitan and Sipadan (Indon./Malay.)"].

$15^{2}$ Ibid., para. 36.
} 
to impact the sovereignty to islands. In rejecting the Indonesian argument, the ICJ noted that Sipadan and Ligitan were not in dispute in 1891, that they were not shown on the map, and thus "that the Members of the Dutch Parliament were almost certainly unaware that two tiny islands lay to the south of the parallel."153 While Indonesia argued that the intention and "main aim" of the parties was to resolve all uncertainties and avoid potential disputes regarding territorial and maritime boundary, ${ }^{154}$ the ICJ concluded that "the object and purpose of the 1891 Convention was the delimitation of boundaries between the parties' possessions within the Island of Borneo itself" and that there was nothing to suggest "that the parties intended to delimit the boundary between their possessions to the east of the islands of Borneo and Sebatik or to attribute sovereignty over any other islands." ${ }^{155}$

Next the ICJ probed deeply into the area's rich history, which involves the Sultans of Banjermasin, Brunei, Bulangan, and Sulu, as well as the activities of the colonial powers such as Germany, Great Britain, the Netherlands, Spain, and the United States. Both parties argued that there were a series of cession treaties and a chain-of-title could be established as a matter of succession from an historic title-holder. The ICJ, however, was not convinced concerning the contention of both parties that there had been an uninterrupted series of transfers of title from the alleged original title-holder to the present one because it had not been established with certainty that Ligitan and Sipadan belonged to the possession of the alleged original title-holder nor that any of the alleged subsequent title-holders had a treaty-based title to these two islands. ${ }^{156}$ Accordingly, the ICJ was left to balance the various, but sparse, effectivités. ${ }^{157}$ The ICJ determined that sovereignty over Pulau Ligitan and Pulau Sipadan belonged to Malaysia ${ }^{158}$ because the ICJ viewed that "the measures taken to regulate and control the collecting of turtle eggs and the establishment of a bird reserve must be seen as regulatory and administrative assertion of authority over territory."159

\footnotetext{
153 Ibid., para. 47.

154 Ibid., para. 49.

155 Ibid., para. 51.

156 Ibid., para. 124.

157 Caron, David D. \& Colson, David A., "International Decision: Sovereignty over Pulau Ligitan and Sipadan”, 97 Am. J. Int'l L. 398, 399 (2003).

158 Pulau Ligitan and Sipadan (Indon. Malay.), para. 150.

159 Ibid., para. 145.
} 


\subsection{Frontier Dispute (Benin/Niger)}

On May 2002, the Republic of Benin and the Republic of Niger agreed to submit to a Chamber constituted by the ICJ for a dispute concerning "the definitive delimitation of the whole boundary between them." Specifically, the ICJ was requested to specify which State owns each of the islands in the River Niger, and in particular Lété Island in Article 2 of the Special Agreement. ${ }^{160}$

The Chamber noted that, under Article 6 of the Special Agreement ("Applicable law"), the rules and principles of international law applicable to the present dispute include "the principle of State succession to the boundaries inherited from colonization, that is to say, the intangibility of those boundaries." The Chamber observed that from the wording of this provision and from the arguments of the Parties the parties had been in agreement on the relevance of the principle of uti possidetis juris for the purpose of determining their common border. However, the Chamber pointed out that it could not exclude $a$ priori the possibility that maps, research or other documents subsequent to the date of independence may be relevant in order to establish, in application of the uti possidetis juris principle, the situation that existed at the time. However, in any event, since the effect of the uti possidetis principle is to freeze the territorial title, the examination of documents posterior to independence cannot lead to any modification of the "photograph of the territory" at the critical date unless such documents clearly express the agreement of the parties to such a change. ${ }^{161}$

The Chamber concluded that neither of the parties succeeded in providing evidence of title on the basis of regulative or administrative acts during the colonial period. Subsequently, the evidence furnished by the parties with respect to effectivités was considered to determine whether it could provide the basis for determining the course of the frontier in the sector of the River Niger and to which of the two States each of the islands in the river belongs. Both parties had periodically claimed rights over the islands, in particular Lété, and also had occasionally performed administrative acts as a display of state authority. However, the Chamber could not conclude that the administration of the island of Lété, which before 1954 was undoubtedly performed by Niger, was effectively transferred to or taken over by Dahomey.

Finally, returning to the concept of uti possidetis juris, the Chamber defined the boundary as the main channel, namely the line of deepest soundings as it

160 Case concerning the Frontier Dispute (Benin/Niger), I.C.J. (July 12, 2005), available at https://www.icj-cij.org/files/case-related/125/125-20050712-JUD-01-oo-EN.pdf (last visited on Jan. 31, 2019) [hereinafter referred to as "Frontier Dispute (Benin/Niger)"], paras. 1-16.

Ibid., paras. 23-31. 
existed at the dates of independence. Accordingly, Benin was granted title to the islands situated between the boundary and the right bank of the river and Niger received title to the islands between that boundary and the left bank of the river. ${ }^{162}$

\subsection{Territorial and Maritime Dispute (Nicaragua v. Honduras)}

The Court rendered its Judgment concerning the question of sovereignty over several small islands lying within the area of overlapping maritime claims on October 8, 2007.163 In respect of sovereignty over the islands of Bobel Cay, Savanna Cay, Port Royal Cay and South Cay, located in the area in dispute, the Court concluded that it had not been established that either Honduras or Nicaragua had title to those islands by virtue of uti possidetis juris. ${ }^{164}$ Having then sought to identify any post-colonial effectivités, the Court found that sovereignty over the islands belonged to Honduras, ${ }^{165}$ as it had shown that it had applied and enforced its criminal and civil law, had regulated immigration, fisheries activities and building activity and had exercised its authority in respect of public works there. ${ }^{166}$

\subsection{Sovereignty over Pedra Branca (Malaysia/Singapore)}

The Court rendered its Judgment determining the sovereignty over an island and two maritime features located at the eastern entrance of the Straits of Singapore on May 23, 2008. ${ }^{167}$ In that Judgment, the Court first indicated that the Sultanate of Johor (predecessor of Malaysia) had original title to Pedra Branca/Pulau Batu Puteh, a granite island on which Horsburgh lighthouse stands. ${ }^{168}$ It concluded, however, that, when the dispute crystallized (1980), title had passed to Singapore, as attested to by the conduct of the Parties (in particular certain acts performed by Singapore à titre de souverain and the failure

\footnotetext{
162 Ibid., paras. 75-102.

163 Territorial and Maritime Dispute between Nicaragua and Honduras in the Caribbean Sea (Nicaragua v. Honduras), Judgment, I.C.J. Reports 2007, p. 659 [hereinafter referred to as "Territorial and Maritime Dispute (Nicaragua v. Honduras)"], paras. 132-227.

164 Ibid., paras. $146-167$.

165 Ibid., para. 321(1).

166 Ibid., paras. 176-208.

167 Sovereignty over Pedra Branca/Pulau Batu Puteh, Middle Rocks and South Ledge (Malaysia/ Singapore), Judgment, I.C.J. Reports 2008, p. 12 [hereinafter referred to as "Sovereignty over Pedra Branca (Malaysia/Singapore)"], paras. 37-299. See Mathias, D. Stephen, "The 2008 Judicial Activity of the International Court of Justice", 103 Am. J. Int'l L. 527, 528-529 (2009); Lathrop, Coalter G., "Case Report: Sovereignty over Pedra Branca/Pulau Batu Puteh, Middle Rocks and South Ledge (Malaysia/Singapore)", 102 Am. J. Int'l L. 828 (2008).

168 Ibid., para. 117.
} 
of Malaysia to react to the conduct of Singapore). ${ }^{169}$ The Court consequently awarded sovereignty over Pedra Branca/Pulau Batu Puteh to Singapore. ${ }^{170}$

As for Middle Rocks, a maritime feature consisting of several rocks permanently above water, the Court observed that the particular circumstances which had led it to find that sovereignty over Pedra Branca/Pulau Batu Puteh rested with Singapore clearly did not apply to Middle Rocks. It therefore found that Malaysia, as the successor to the Sultan of Johor, should be considered to have retained original title to Middle Rocks. ${ }^{171}$

Finally, with respect to the low-tide elevation South Ledge, the Court noted that it fell within the apparently overlapping territorial waters generated by Pedra Branca/Pulau Batu Puteh and by Middle Rocks. Recalling that it had not been mandated by the Parties to delimit their territorial waters, the Court concluded that sovereignty over South Ledge belongs to the State in whose territorial waters it lies. ${ }^{172}$

\subsection{Territorial and Maritime Dispute (Nicaragua v. Columbia)}

In its Judgment rendered on the merits of the case on November 19, 2012, the Court found that the territorial dispute between the Parties concerned sovereignty over the features situated in the Caribbean Sea (the Alburquerque Cays, the East-Southeast Cays, Roncador, Serrana, Quitasueño, Serranilla and Bajo Nuevo) which were all above water at high tide and which were therefore islands capable of appropriation. ${ }^{173}$ The Court noted, however, that Quitasueño comprised only a single, tiny island, known as QS 32 , and a number of low-tide elevations. The Court then observed that, under the terms of the 1928 Treaty concerning Territorial Questions at Issue between Colombia and Nicaragua, Colombia not only had sovereignty over the islands of San Andrés, Providencia and Santa Catalina, but also over other islands, islets and reefs "forming part" of the San Andrés Archipelago. Thus, in order to address the question of sovereignty, the Court first needed to ascertain what constituted the San Andrés Archipelago. It concluded, however, that neither the 1928 Treaty nor the historical documents conclusively established the composition of that Archipelago. ${ }^{174}$ The Court therefore examined the arguments and evidence not based on the composition of the Archipelago under the 1928 Treaty. It found that neither

\footnotetext{
169 Ibid., para. 276.

170 Ibid., para. 300.

171 Ibid., para. 290.

172 Ibid., paras. 297-299.

173 Territorial and Maritime Dispute (Nicaragua v. Columbia), Judgment, I.C.J. Reports 2012, p. 624, paras. 25-103.

174 Ibid., paras. 40-56.
} 
Nicaragua nor Colombia had established that it had title to the disputed maritime features by virtue of uti possidetis juris, because nothing clearly indicated whether these features were attributed to the colonial provinces of Nicaragua or of Colombia. ${ }^{175}$

The Court then considered whether sovereignty could be established on the basis of State acts manifesting a display of authority on a given territory (effectivités). It regarded it as having been established that for many decades Colombia had continuously and consistently acted à titre de souverain in respect of the maritime features in dispute. This exercise of sovereign authority had been public and there was no evidence that it had met with any protest from Nicaragua prior to 1969 , when the dispute had crystallized. ${ }^{176}$ Moreover, the evidence of Colombia's acts of administration with respect to the islands was in contrast to the absence of any evidence of acts à titre de souverain on the part of Nicaragua. ${ }^{177}$ The Court also noted that, while not being evidence of sovereignty, Nicaragua's conduct with regard to the maritime features in dispute, the practice of third States and maps afforded some support to Colombia's claim. ${ }^{178}$ The Court concluded that Colombia, and not Nicaragua, had sovereignty over the islands at Alburquerque, Bajo Nuevo, East-Southeast Cays, Quitasueño, Roncador, Serrana and Serranilla. ${ }^{179}$

\subsection{Frontier Dispute (Burkina Faso/Niger)}

The Court rendered a ruling to determine the disputed border between Burkina Faso (formerly known as Upper Volta) and Niger on April 16, $2013 .{ }^{180}$ This dispute resulted from the murky boundary line between two countries which had been drawn by French colonies. Before declaring independence in 1960, two countries were French colonies, forming part of French West Africa. In 1926, the French president issued a decree transferring some territories from Upper Volta and the former Military Territory of Niger to the colony of Niger and provided that an Arrêté (Order) of the Governor-General of French West Africa was to determine the boundary between the two colonies. The Governor-General ad interim of French West Africa issued the Arrêté with

\footnotetext{
175 Ibid., paras. $57-65$.

176 Ibid., paras. $67-71$.

177 Ibid., paras. $72-84$.

178 Ibid., paras. $85^{-102}$.

179 Ibid., paras. 103.

180 Frontier Dispute (Burkina Faso/Niger), Judgment, I.C.J. Reports 2013, p. 44 [hereinafter referred to as "Frontier Dispute (Burkina Faso/Niger)"], paras. 60-112. See Yee, Sienho, "The 2013 Judicial Activity of the International Court of Justice”, 109 Am. J. Int'l L. 339, 339-349 (2015).
} 
a view to "fixing the boundaries of the colonies of Upper Volta and Niger"181 on August 31, 1927. The object and purpose of the Arrêté was clarified by its Erratum of October 5, 1927. The terms of the Arrêté and its Erratum occupied an important place in the delimitation of the boundary.

\section{The “Three-Staged Judicial Review” in Territorial Decisions}

Textbooks on international law describe territorial disputes in two ways: by listing complex items in which it is difficult to find systemic logic 182 or by listing relatively fewer items in which each item involves too much information. ${ }^{183}$ Sometimes it appears that only occupation by force can establish dominion over a territory with few legal principles practically applicable to territorial disputes and with little or no order for processing legal applications. However, if arbitral awards and judgments concerning territorial disputes are carefully examined, it can be determined that the Tribunal and the Court first examined the legal basis and subsequently applied the principle of effectivités to prevent non liquet in case that they found that legal ground concerning territorial acquisition did not exist. The author refers to the whole legal process as "three-staged judicial review."

\subsection{First Stage of Judicial Review: Legal Basis}

In the first stage of the "three-staged judicial review" used in the reasoning of territorial decisions, if a disputed territory is included in the applicable scope of the peace treaty, the treaty concerning boundary delimitation, the uti possidetis principle or the adjudication award, they will then be considered to be decisive proof in deciding which sovereignty exists over that territory. The

\footnotetext{
181 Frontier Dispute (Burkina Faso/Niger), para.19.

182 See, for example, Brownlie, Ian, Principles of Public International Law 125-67 (6th ed., 2003).

183 See, for example, Fenwick, C. G., International Law 404-35 (1965), pp. 404-35;Jennings, R. Y., The Acquisition of Territory in International Law 16-35 (1963); Jennings, R. Y. \& A. Watts (eds.), 1 Oppenheim's International Law 677-718 (1992); Lindley, M. F., The Acquisition and Government of Backward Territory in International Law 123-302 (1926); O' Connell, D. P., 1 International Law 405-48 (1970); Sharma, S., Territorial Acquisition, Disputes and International Law 35-16o (1997); Shaw, M., International Law 338-54 (1997); Shaw, M., Title to Territory in Africa 17-26 (1986) [hereinafter referred to as "Shaw, Title to Territory"]; Shearer, I. A., Starke's International Law 144-55 (1994).
} 
decisive binding effect of treaties upon apportioning territory and delimiting boundaries may result from the consent of relevant states. ${ }^{184}$

\subsubsection{Treaties concerning Boundary Delimitation}

Treaties concluded between two parties (including their predecessors) concerning boundary delimitation are the primary legal basis by which to determine which country has sovereignty over the territory at issue. Cases in which this approach was established include the Pulau Ligitan and Sipadan (Indon./Malay.) [The 1891 Convention between Great Britain (predecessor to Malaysia) and the Netherlands (predecessor to Indonesia) ${ }^{185}$, Kasikili/Sedudu Island (Bots. v. Namib.) [The Anglo-German Treaty of 1980], Land Boundary (Cameroon v. Nig.) [The relevant instruments (Milner-Simon Declaration, 1919; Thomson-Marchand Declaration, 1929-1930; Henderson-Fleurian Exchange of Notes, 1931)], Territorial Dispute (Libya/Chad) [The Treaty of Friendship and Good Neighborliness between the French Republic and The United Kingdom of Libya of 10 August 1955], Certain Frontier Land (Belg./Neth.) [The Boundary Convention of 1843], and Temple of Preah VIhear (Cambodia v. Thai.) [The Franco Siamese boundary Treaty of 1907].

In examining the issue of territorial acquisition, special references must be made to boundary treaties, whereby either additional territory is acquired or lost or uncertain boundaries are clarified by agreement between the states concerned. ${ }^{186}$ As such, boundary treaties constitute the root of the title. Boundary treaties establish the critical date and they will shift the pertinent date of crystallization of territorial rights. ${ }^{187}$ Furthermore, an objective territo-

184 See Shaw, M., "The Heritage of States: The Principle of Uti Possidetis Juris Today", 67 Brit. Y. B. Int'l L. 77, 84 (1996) ("The best means to ensure stability in general is to rely upon the consent of the parties themselves, so that once the relevant parties have by whatever means agreed upon a boundary line, that agreement constitutes a binding obligation.... This consent may be manifested in a variety of ways, of which express agreement through a binding treaty is but the most apparent.").

185 Convention Between Great Britain and the Netherlands Defining the Boundaries in Borneo, June 20, 1891, Gr. Brit.-Neth.; Pulau Ligitan and Sipadan (Indon./Malay.), para. 23.

186 Shaw, M., Title to Territory (2005) [hereinafter referred to as "Shaw, Title to Territory"], at $x v i$.

187 See Land, Island and Maritime Frontier Dispute (El Sal./Hond.), para. 67. ("The principle of uti possidetis juris is sometimes stated in almost absolute terms, suggesting that the position at the date of independence is always determinative; in short, that no other critical date can arise. ... [However, a] later critical date clearly may arise, for example, either from adjudication or from a boundary treaty. Thus in the previous Latin American boundary arbitrations it is the award that is now determinative, even though it is based upon a view of the uti possidetis juris position. The award's view of the uti possidetis juris position prevails and cannot now be questioned juridically, even if it could be questioned 
rial regime established by a boundary treaty will exist outside of the particular boundary treaty and thus will continue even if the treaty in question itself ceases to apply. ${ }^{188}$

This being so, many boundary disputes in fact revolve around the question of interpretation of the treaty. ${ }^{189}$ It is accepted that a treaty should be interpreted according to Article 31 and 32 of the Vienna Convention on the Law of Treaties 1969, 'in good faith, in accordance with the ordinary meaning to be given to its terms in their context and in the light of the object and purpose.'190 Essentially the aim is to determine the 'common will' of the parties. ${ }^{191}$ Because many of the boundary treaties that need to be interpreted long pre-date the Vienna Convention, ${ }^{192}$ the problem of the applicability of its provisions has arisen. Courts have taken the view that the Convention, in this respect at least, represents customary international law thus apparently obviating the problem. ${ }^{193}$

From the principle of stability a presumption exists that the Tribunal and the Court will favor an interpretation of a treaty creating a boundary that holds that a permanent, definite and complete boundary was established..$^{194}$ The basis of this thought is inferred from the following four cases. In the

historically. So for such a boundary the date of the award has become a new and later critical date. Likewise, there can be no question that the parts of the El Salvador/Honduras boundary fixed by the General Treaty of Peace of 1980 now constitute the boundary and 1980 is no the critical date.").

188 See Territorial Dispute (Libya/Chad), at 37, para. 72-73 ("The establishment of this boundary is a fact which, from the outset, has had a legal life of its own, independently of the fate of the 1955 Treaty... A boundary established by treaty thus achieves a permanence that the treaty itself does not necessarily enjoy. The treaty can cease to be in force without in any way affecting the continuance of the boundary.").

189 Shaw, Title to Territory, supra note 186 , at $x v i i$.

190 Kasikili/Sedudu Island (Bots./Namib.), at 1059, para. 18; Territorial Dispute (Libya/Chad), at 21-22, para. 41; Pulau Ligitan and Sipadan (Indon./Malay.), at 23-24, para. 37; Territorial Questions (Qatar v. Bahr.) (Jurisdiction and admissibility), para. 33, available at https:// www.icj-cij.org/files/case-related/87/087-19940701-JUD-01-oo-EN.pdf (last visited on Jan. 31, 2019).

191 Eritrea-Ethiopia Boundary Commission (EEBC): Decision Regarding Delimitation of the Border between the State of Eritrea and the Federal Democratic Republic of Ethiopia, reprinted in 41 I.L.M. 1057, 1073 (2002) [hereinafter referred to as "Decision Regarding Delimitation of the Border (Eri. v. Eth.)"]; Land Boundary (Cameroon/Nig.), at 48, para. 59 ("[T]he Court must seek to ascertain the intention of the parties at the time.").

192 See Article 4 of the Convention providing that the Convention applies only to treaties concluded after the coming into force of the Convention itself (27 January 1980).

193 See Pulau Ligitna and Sipadan (Indon./Malay.), at 23-24, para. 37; Kasikili.Sedudu Island (Bots./Namib.), at 1059-6o.

194 See Shaw, supra note 184 , at 93. 
case involving the Treaty of Lausanne the Permanent Court noted, "It is ... natural that any Article designed to fix a frontier should, if possible, be so interpreted that the result of the application of its provisions in their entirety should be the establishment of a precise, complete and definitive frontier."195

This approach was supported in the case of Certain Frontier Land (Belg./ Neth.) and in the case of Territorial Dispute (Libya/Chad). In the former case, the Court noted the Preamble to a Boundary Convention as recording the common intention of the parties to "fix and regulate all that relates to the demarcation of the frontier between the Kingdom of the Netherlands and the Kingdom of Belgium,"196 and held that "Any interpretation under which the Boundary Convention is regarded as leaving in suspense and abandoning for a subsequent appreciation of the status quo the determination of the right of one State or the other to the disputed plots would be incompatible with that common intention." 197 In the latter case, the Court noted that the relevant 1955 Franco-Libyan Treaty must be considered to have determined a permanent frontier. The Court stated that "there was nothing in the 1955 Treaty to indicate that the boundary agreed was to be provisional or temporary; on the contrary it bears all the hallmarks of finality. Once agreed, the boundary stands, for any other approach would vitiate the fundamental principle of the stability of boundaries." ${ }^{198}$ In other words, in the absence of any indication to the contrary, the intention of the boundary treaty must be presumed to be conclusive and determinative. ${ }^{199}$

Furthermore, Judge Franck stated in his dissenting opinion in the Pulau Ligitan and Sipadan (Indon./Malay.) case, that "the Court should confirm precedents making rebuttable presumption that a line to fix a frontier should, if possible, be so interpreted that the result of the application of its provisions in their entirety conduces to establishment of a precise, complete and definitive

195 Article 3, Paragraph 2, of the Treaty of Lausanne (Frontier between Turkey and Iraq), PCIJ, Series B, No. 12 (Nov. 21, 1925), at 20.

196 Certain Frontier Land (Belg./Neth.), at 221.

197 Ibid., at 221-222. The Court reached the conclusion that the Boundary Convention was intended to determine, and did determine, as between the two States, to which State the various plots in each commune belonged. Under its terms, the disputed plots were determined to belong to Belgium. Ibid., at 222.

198 Territorial Dispute (Libya/Chad), at 37; see also at 44 (Judge Shahabuddeen pointed out in his separate opinion that the colonial boundary treaty considered in that case "must ... be construed so as to produce a comprehensive definition of the frontiers" unless there are "compelling reasons to the contrary.").

199 Shaw, supra note 184 , at 92. 
frontier."200 The implication of the rebuttable presumption was explained as follows:

Even were the circumstantial evidence that the Parties thought they were resolving all the territorial problems arising out of their overlapping ... claims, inconclusive, it is surely sufficient to invoke the rebuttable presumption, based on the commonsense and experience of diplomacy and recognized by several international tribunals, to the effect that when States negotiate a boundary allocating or confirming their respective areas of sovereignty over territories, these shall be presumed to have intended to resolve all outstanding and potentially disputatious claims in the area in question, subject only convincing evidence to the contrary.

However, the Court ultimately concluded that "Article IV, interpreted in its context and in the light of the object and purpose of the Convention, - does not establish any allocation line further eastwards," ${ }^{201}$ noting that "any ambiguity could have been avoided had the Convention stipulated that.... In these circumstances the silence in the text cannot be ignored."202 In other words, the Court rejected maintaining the presumption that the Parties negotiating a boundary allocating or confirming their respective areas of sovereignty over territories, have intended to resolve all the territorial problems arising out of their conflicting claims, because of the ambiguity of the terms which could have been avoided had the Parties of the Convention intended to do so. Therefore, "the presumption of the conclusiveness and completeness of defined frontiers" 203 cannot apply where an agreement even shows a slightly implicit intention that it should not be completed or final, such as the case where "the terms of the agreement has the ambiguity which could have been avoided had the agreement expressly stipulated their meaning," 204 as well as cases in which an agreement explicitly manifests the intention that it should not be complete or final, or where the agreement itself does not establish or recognize an international boundary. ${ }^{205}$

\footnotetext{
200 Pulau Ligitan and Pulau Sipadan (Indon./Malay.) (Franck, J., dissenting), at 1 \& 9-11.

201 Pulau Ligitan and Sipadan (Indon./Malay.), at 44, para. 92

202 Ibid., at 25, para. 42.

203 Pulau Ligitan and Sipadan (Indon./Malay.) (Franck, J., dissent), at 9.

204 Pulau Ligitan and Sipadan (Indon./Malay.), at 1.

205 Shaw, supra note 184, at 92.
} 
The principle of stability of frontiers applies "when two countries establish a frontier between them."206 The proper use of the principle of stability is in the interpretation and application of the treaty if it exists, ${ }^{207}$ and not in proof of the existence of the treaty. ${ }^{208}$

\subsubsection{Peace Treaties}

A peace treaty can be reviewed as a special kind of boundary treaty in terms of the binding effect on third-party states. As demonstrated in the Lausanne Peace Treaty in the Eritrea-Yemen Arbitration (Phase I: Territorial Sovereignty), peace treaties 209 are the primary legal basis by which to determine which country has sovereignty over the territory at issue. A special kind of boundary treaty, like a peace treaty, is accepted to establish an objective territorial regime valid erga onmes. ${ }^{210}$ Jurists recognize the existence of the power of disposition or assignment, to be exercised jointly through a peace treaty over the territory of the defeated states, but they find it difficult to suggest, or to agree upon, a satisfactory legal basis for this concept. Some translate political realities into legal forms by purporting that the community of states has delegated

206 Territorial Dispute (Libya/Chad) (Shahabuddeen, J., separate), at 49; Pulau Ligitan and Sipadan (Indon./Malay.), paras. 34-92.

207 Shaw, Title to Territory, supra note 186, at 50.

208 On the contrary, Judge Franck, in the dissenting opinion of Pulau Ligitan and Sipadan (Indon./Malay.), tried to use the principle of stability of boundaries to prove the existence of the contested agreement, stating that "[T] here is a circumstantial evidence that the Parties thought they were resolving all the territorial problems arising out of their overlapping imperial claims in the Borneo area. Even was that evidence inconclusive, it is surely sufficient to invoke the rebuttable presumption, based on the commonsense and experience of diplomacy and recognized by several international tribunals, to the effect that when States negotiate a boundary allocating or confirming their respective areas of sovereignty over territories, these shall be presumed to have intended to resolve all outstanding and potentially disputatious claims in the area in question, subject only to convincing evidence to the contrary." (Pulau Ligitan and Sipadan (Indon./Malay.) (Franck, J., dissent), para. 45). However, the proof must be made in other ways.

209 See, for example, The Treaty of Verdun (845); Peace of Westphalia (1648); Treaty of Paris (1898); Treaty of Versailles (1915); The Peace Treaty of San Francisco (1950).

210 See Eritrea-Yemen Arbitration (Phase I: Territorial Sovereignty), para. 153 ("Boundary and territorial treaties made between two parties are res inter alios acta vis-á-vis third parties. But the special category of treaties [such as the peace treaty] represents a legal reality that necessarily impinges upon third states, because they have effect erga onmes. If State A has title to territory and passes it to State B, then it is legally without purpose for State C o invoke the principle of res inter alios acta, unless its title is better than that of A (rather than of B). In the absence of such better title, a claim of res inter alios acta is without legal import."). 
such a power to the 'principal' or 'great' powers. ${ }^{211}$ Others, at least in relation to the Second World War, postulate a right to impose measures of security, which may include frontier changes, on an aggressor consequent on his defeat in a war of collective defense and sanction. ${ }^{212}$

To understand the evidentiary value of a peace treaty in territorial awards and decisions, it is valuable to examine the need to grasp the issue of whether a peace treaty is binding to a non-party state as well as to a party state. Concerning the third-party effect of a peace treaty, in the Eritrea-Yemen Arbitration (Phase I: Territorial Sovereignty), the Lausanne Peace Treaty was "regarded as legal basis for the establishment of treaty obligations and rights valid erga onmes, that is, so called "objective regimes."213

\subsubsection{The Principle of Uti Possidetis}

As demonstrated in the case of the Frontier Dispute (Burk. Faso/Mali), EritreaYemen Arbitration (Phase I: Territorial Sovereignty), Kasikili/Sedudu Island (Bots./Namib.) and Land Boundary (Cameroon v. Nig.), the principle of uti possidetis juris ${ }^{214}$ has been one of the most important legal basis by which the Courts judge the issue of territorial sovereignty. In the Frontier Dispute (Burk. Faso/Mali) case, the Court considered the question of whether uti possidetis juris always trumps self-determination even in the new Charter-era. In holding that uti possidetis takes priority over self-determination, the court expressly relied on a particular regional practice in Africa, according to which respect for boundaries existing at independence was seen as a necessity for realizing the practical benefits of self-determination. The Court did not suggest that this decision of the conflict between two principles would necessarily apply in any other region. ${ }^{215}$

Accordingly, the uti possidetis position can be qualified by adjudication and by treaty, as well as it can be qualified by acquiescence or recognition. Naturally, these factors should operate where there is sufficient evidence to

\footnotetext{
211 Brownlie, supra note 182 , at $130-31$.

212 Ibid.

213 Eritrea-Yemen Arbitration (Phase I: Territorial Sovereignty), para. 153; Damrosch, Lori F. etc., International Law: Cases and Materials 517, 519 (2001).

214 This principle has been expressed as follows: "When the common sovereign power was withdrawn, it became indispensably necessary to agree on a general principle of demarcation, since there was a universal desire to avoid resort to force, and the principle adopted was a colonial utipossidetis; that is, the principle involving the preservation of the demarcation under the colonial regimes corresponding to each of the colonial entities that was constituted as a State." Brownlie, supra note 182, at 133 .

215 See Frontier Dispute (Burk. Faso v. Mali.), para. 25; Frontier Dispute (Burk. Faso v. Mali), para. 26.
} 
demonstrate that the parties have, in effect, clearly accepted a variation, or at least an interpretation, of the uti possidetis juris position. ${ }^{216}$

The application of the principle of uti possidetis resulting from colonial dominance may be reinforced by the terms of the compromis itself. In the Decision Regarding Delimitation of the Border (Eri. v. Eth.) case, the parties referred specifically to "the principle of respect for boundary existing at the moment of independence" and "pertinent colonial treaties."217 The Boundary Commission considered the statement acceptance that the date in question for the determination of the borders was that of the independence of Eritrea (April 23, 1993). ${ }^{218}$ As a consequence, developments subsequent to that date were not to be considered insofar as they were seen as a continuance or confirmation of a line of conduct already clearly established, or assumed the form of express agreements between the parties. ${ }^{219}$ In the Frontier Dispute (Benin/ Niger), under Article 6 of the Special Agreement ("Applicable Law"), the rules and principles of international law applicable to the present dispute included "the principle of State succession to the boundaries inherited from colonization, that is to say, the intangibility of those boundaries." It follows from the wording of this provision and from the argument of the Parties that they were in agreement on the relevance of the principle of uti possidetis for the purposes of determining their common border. ${ }^{220}$ Even when there no frontier exists which was fully determined by direct or delegated legislation during the colonial period, the two Parties both might agree that when they became independent there was a definite frontier. ${ }^{221}$

\subsubsection{Adjudication (Boundary Award)}

Just as in the case of a boundary treaty, a territorial dispute may be resolved and title established or confirmed by an award or decision of a court or tribunal, or to put the proposition another way, boundary awards (sometimes termed adjudication), like boundary treaties, may constitute roots or sources of legal title to territory. ${ }^{22} \mathrm{~A}$ decision by the International Court providing that State A has title to a particular territory or determining the boundary line

\footnotetext{
216 See Land, Island and Maritime Frontier Dispute (El Sal. v. Hond.), at 401, para. 67.

217 See Agreement Between the Government of the Federal Democratic Republic of Ethiopia and the Government of the State of Eritrea, Article 4, Paragraph 1, reprinted in 40 I.L.M. 260, 261 (2001).

218 See Decision Regarding Delimitation of the Border (Eri. v. Eth.), at 1078, para. 3.36.

219 Ibid.

220 Frontier Dispute (Benin/Niger), at 21, para. 23.

221 See Frontier Dispute (Burk. Faso v. Mali), at 570, para. 30.

222 Brownlie, supra note 182, at 102.
} 
between two states will constitute establishment or confirmation of title that will be binding on the parties themselves, and for all practical purposes, on all states in the absence of maintained protest. ${ }^{223}$ Additionally, boundary allocation decisions that do not constitute international judicial decisions or arbitral awards may be binding, provided that it can be shown that the parties consented to the initial decision. ${ }^{224}$

\subsection{Second Stage of Judicial Review: A Chain-of-Title through Cession and Succession}

In the second stage of the "three-staged judicial review," the Tribunal and the Court examined whether cession treaties and the fact of succession established definitive title on the disputed territory at issue. Historical claims to territory are based on historical priority (first possession) or duration (length of possession by cession and succession which constitute a chain-of-title). ${ }^{225}$ Historical claims create an underlying entitlement of territory, regardless of whether a state has actual or constructive possession of the land at the time of the claim. ${ }^{226}$ Most conflict over territory is based on historical claims (some of which are quite dubious). ${ }^{227}$ In other words, the use of historical or past data as part of a contemporary claim is not unusual in territorial disputes. ${ }^{28}$ The parties to cases frequently provide the tribunal or court with copious materials dealing with a wide range of what may be regarded as relevant activities over time..$^{229}$

223 Shaw, Title to Territory, supra note 186 , at xviii.

224 See Case concerning Maritime Delimitation and Territorial Questions between Qatar and Bahrain, para. 110-48. Even if the British decision of 11 July 1939 was not a matter of adjudication in the strictest sense, quasi-adjudication (mere administrative decision during colonial times) was accepted as a conclusive mode of territorial acquisition. Therefore, the Court considered it unnecessary for it to rule on the argument of the Parties based on the existence of an original title, effectivités, and the applicability of uti possidetis juris to the case (Ibid., para. 148).

225 See Burghardt, Andrew, "The Bases of Territorial Claims", 63 Geographical Review 225, 230 (1973); Sumner, supra note 79, at 1789 .

226 See Sharma, supra note 183 , at 31 ("The most common way in which a historical claim is advanced is to refer to a set of historical facts to establish that they logically lead to a right to historic possession").

227 Knight, David B., "People Together, Yet Apart: Rethinking Territory, Sovereignty, and Identities", in Reordering the World: Geopolitical Perspectives on the Twenty-First Century (Demko, George J. \& Woods, William B. (eds.), 1994).

228 Shaw, Title to Territory, supra note 186, at $x x$.

229 Ibid. 
Cession and succession, of course, can be defined as legal basis. ${ }^{230}$ However, we must recall that a chain-of-title by succession and cession did not function at all as long as the legal basis of the first staged of the "three-staged judicial review" existed. In the case of the Territorial Dispute (Libya v. Chad), the Court stated that it did "not need to deal with the history of the dispute,"231 since " $\mathrm{t}$ ] $\mathrm{he} 1955$ Treaty completely determined the boundary between Libya and Chad."232

Although the Court entered into reviewing a chain-of-title, it never turned out to be decisive proof of establishing a title over the disputed territory in most territorial dispute cases, as was demonstrated in the cases of Palmas Island (U.S. v. Neth.), Clipperton Island (Fr. v. Mex.), Eastern Greenland (Den. v. Nor.), Minquiers and Ecrehos (Fr. v. U.K.), Eritrea-Yemen Arbitration (Phase I: Territorial Sovereignty) and Pulau Ligitan and Sipadan (Indon./Malay.). Both parties of the cases submitted in vain an extraordinarily vast amount of historic records (including maps and exchange of correspondence) to the Court.

However, it is not easy to prove that cession or succession over the territory at issue is legally valid. In order to demonstrate validity of cession and succession in front of the Court, the claimant state must prove that its predecessor state exercised dominium over the disputed territory at the time when transfer or succession existed. ${ }^{233}$ For example, in the case of Palmas Island (U.S. v. Neth.), the immediate foundation of the United States' claim was a Treaty of Peace of 1898 by which Spain ceded the Philippines, including the Island of Palmas, to the United States. However, it was admitted that this treaty could not be interpreted as transferring rights over territory to which Spain had no

230 See Brownlie, supra note 182, at 131 (That is to say, right to possess certain territory as sovereign may be conferred by agreement between the intending grantor and grantee: if the grantee takes possession in accordance with the treaty, the treaty provides the legal basis of sovereignty.).

231 Territorial Dispute (Libya v. Chad), at 40, para. 76. See also Crawford, "The General Assembly, the International Court and Self-determination", in Lowe and Fitzmaurice (eds.), Fifty Years of the International Court of Justice 585, 602 (1996).

232 Territorial Dispute (Libya v. Chad), at 40, para. 76.

233 The reason is as follows; since the essence of cession and succession is the transference of title from one sovereign to another, it is clear that the former can transfer to the latter no more rights than are actually possessed. See Shaw, Title to Territory, supra note 186, at xix. Accordingly, if the title claimed by the transferring state is in fact defective, this cannot be cured by the transfer alone and the stat to which the territory is transferred will have no more than the defective title. See Palmas Island (U.S. v. Neth.), at 879-80 ("[W]hatever may be the right construction of a treaty, it cannot be interpreted as disposing of the rights of independence third Powers."). 
title. The validity of the United States' claim therefore depended on whether Spain had an effective title to the island as of the date the treaty was signed. ${ }^{234}$

Moreover, even if a legal title is alleged to have existed in the past, its evidential power has apparently diminished as the new rule of international law evolved with regard to territorial acquisition (e.g., the evolution of the 'effective occupation doctrine' during the 19th and 2oth centuries) due to the principle of inter-temporal law. ${ }^{235}$ Consequently, in cases in which the act required to confer title imposes a continuing obligation, the fulfillment of that obligation by the state is evaluated according to the current law at each stage. Thus, "if the principle of 'effective occupation' governed the acquisition of sovereignty over territory after a state first took possession of a territory by discovery or symbolic act, the state's title to that territory thereafter would depend on its adherence to the evolving principles of international law."236

Therefore, the Tribunal and the Court prefer to go have recourse to modern manifestations of sovereign activity in the absence of overwhelming evidence that the historical data provided was sufficient to meet the criteria required for an historic title. Here, the Minquiers and Ecrehos (Fr. v. U.K.) case is instructive. Both the U.K. and France laid claims to the islets and rocks in question on the basis of an ancient or original title going back to 1066 (the Norman invasion of England) ${ }^{237}$ or 1204 (the French capture of Normandy), ${ }^{238}$ respectively. However, the Court stressed that the question of sovereignty "must ultimately depend on the evidence which relates directly to the possession of these groups" 239 and declared that "[w] hat is of decisive importance in the opinion of the Court, is not indirect presumption deduced from events in the Middle Ages, but the evidence which relates directly to the possession of the Ecrehos and Minquiers groups."240 This approach was followed in the Eritrea-Yemen

234 See also Munkman, A.L.W., "Adjudication and Adjustment - International Judicial Decisions and the Settlement of Territorial and Boundary Disputes", 46 Brit. Y. B. Int'l L. 1, 47-48 (1972-73).

235 See Palmas Island (U.S. v. Neth.), at 845 ("[T] he existence of the right, in other words, its continued manifestation, shall follow the conditions required by the evolution of the law.").

236 Palmas Island (U.S. v. Neth.), at 845. See also Ott, David H., Public International Law in the Modern World 105 (1987), at 109. The concession and succession of 'ancient title' are less significant when they purport to base a claim on some distant historic connection with the territory which has in fact long been superseded by the effects of later historical developments, which, in most cases, related to the European imperialism.

237 Minquiers and Ecrehos (U.K. v. Fr.), at 53.

238 Ibid., at $53-54$.

239 Ibid., at 55 .

240 Ibid., at 57. 
Arbitration (Phase I: Territorial Sovereignty) case, where the tribunal took the view that if there has been between the parties "much argument about claims to very ancient titles, it is the relatively recent history of use and possession that ultimately proved to be a main basis of the Tribunal decisions."241

If neither party is permitted sovereignty on the basis of historic evidence, the usefulness of the evidence can apply in the next stage of the "three-staged judicial review," or effectivités, as will be discussed later. The Court can determine if the evidence amounts to effective domination and continued display of effective control - which is a matter of fact, while the issue of succession of title seems a purely legal issue. In short, evidence submitted to prove each party's legal title based on a chain-of-title through succession and cession in the second stage would be converted to demonstrate effective control over the territory in question in the third stage of the "three-staged judicial review."242

\subsection{Third Stage of Judicial Review: Effectivités}

If the Court cannot resort to the legal basis defined in the first two stages, the proceedings will enter into the next stage. In the absence of a legal basis in the form of treaties, grants of awards or application of uti possidetis (first stage), or of a chain-of-title through cession or succession (second stage), the considerations deliberated by the Court may include evidence of actual administration and legislation over disputed areas. ${ }^{243}$ In other words, the exercise of

241 Eritrea-Yemen Arbitration (Phase I: Territorial Sovereignty), para. 450.

242 For example, in Pulau Ligitan and Sipadan (Indon./Malay), the Court held that "[T]he United States relinquished any claim it might have had to Ligitan and Sipadan pursuant to the 1930 Convention and no other State asserted its sovereignty over those islands at that time or objected to their continued administration by the State of North Borneo. The activities of the State of North Borneo which took place before the conclusion of the Convention cannot be seen as acts "à titre de sourverain", as Great Britain did not at that time claim sovereignty on behalf of the State of North Borneo over the islands beyond the 3-marine-league limit." Pulau Ligitan and Sipadan (Indon./Malay), para. 142. For that reason the Court did not conclude that the two islands belonged to Malaysia on the basis of a chain-of-title through succession and a cession treaty. However, the Court held that "[W]ith regard to the effectivités relied upon by Malaysia, the administrative activities of the State of North Borneo cannot be ignored either since Great Britain took the position that the State of North Borneo was entitled to administer the islands, which was formally recognized by the United States through the 1930 Convention." Ibid., para. 142. See also Sir Gerald Fitzmaurice, The Law and Procedure of the International Court of Justice (1986), Vol. I, at 274-75.

243 See e.g., Minquiers and Ecrehos (Fr. v. U.K.), at 57; Munkman, supra note 234, at 99. 
sovereign activity (effectivités) $)^{244}$ cannot overturn an established legal title ${ }^{245}$ and can be considered only in the absence of any legal title.

In the third stage of the "three-staged judicial review," the Court decides the status of dominium on the basis of effective control. The rationale is to stabilize a territorial relationship between the states and to allow sovereignty to the state that can properly fulfill the duties corresponding to exclusive sovereignty over the territory. Therefore, even though the legal basis could not be found, the Court granted title to the state that exercised continuous, peaceful and effective control over the territory.

Even if proof, such as the existence of a peace treaty, a treaty concerning boundary delimitation, the principle of uti possidetis, adjudication, or a chainof-title through cession and succession (as mentioned above) seemed to exist, the Court would not adopt it in most cases. In the Palmas Island (U.S. v. Neth.), Clipperton Island (Fr. v. Mex.), Eastern Greenland (Den. v. Nor.), Minquiers and Ecrehos (Fr. v. U.K.), Eritrea-Yemen Arbitration (Phase I: Territorial Sovereignty), and Pulau Ligitan and Sipadan (Indon./Malay.) cases, the alleged legal basis turned out not to prescribe definitively the territorial sovereignty over the disputed territory. For that reason, most territorial disputes are judged in favor of the preponderance of effective control except in cases such as the Territorial Questions (Qatar v. Bahr.) and Land Boundary (Cameroon v. Nig.), ${ }^{246}$ Kasikili/

244 It was described as 'continuous and peaceful display of territorial sovereignty.' Island of Palmas, at 839; Eritrea-Yemen Arbitration (Phase I: Territorial Sovereignty), para. 451.

245 Land Boundary (Cameroon v. Nig.), at 54-55, paras. 68 \& 70 (In this case, the territory at issue was effectively administered by Nigeria and Cameroon was alleged to possess the legal title. The Court found that the situation was essentially one in which the effectivités adduced by Nigeria did not correspond to the law as long as there was no acquiescence by Cameroon in the abandonment of its title in the area in favor of Nigeria. Accordingly, the Court concluded that preference should be given to the holder of the title, Cameroon.). See also Frontier Dispute (Burk. Faso/Mali), at 587, para. 63; Territorial Dispute (Libya/ Chad), at $75^{-76}$, para. 38 ("Where the act does not correspond to the law, where the territory which is the subject of the dispute is effectively administered by a State other than the one possessing the legal title, preference should be given to the holder of the title. In the event that the effectivités does not co-exist with any legal title, it must invariably be taken into consideration.").

246 " $[\mathrm{I}] \mathrm{t}$ is impossible to read the records of the decision in cases as to territorial sovereignty without observing that in many cases the tribunal has been satisfied with very little in the way of the actual exercise of sovereign rights, provided that the other State could not make a superior claim (Eritrea-Yemen Arbitration (Phase I: Territorial Sovereignty), para. 452), with reference to Eastern Greenland (Den. v. Nor.)). We can interpret "provided that the other State could not make a superior claim" as "provided that the legal title could not be admitted in the 1st and 2nd step." The holding subsequently also reaffirmed by Territorial Questions (Qatar v. Bahr.), para. 198 and Pulau Ligitan and Sipadan (Indon./ Malay.), para. 134. 
Sedud Island (Bots. v. Namib.), Temple of Preah Vihear (Cambodia v. Thai.), Territorial Dispute (Libya/Chad), Certain Frontier Land (Belg./Neth.), Land, Island and Maritime Frontier Dispute (El Sal. v. Hond.), and Frontier Dispute (Burk. Faso v. Mali). The reason most territorial cases were solved on the basis of effective control is the lack of sufficient legal basis. Without an explicit legal basis, the Court has no alternative but to enter the next stage, which confers legal title as a fait accompli.

The traditional modes of territorial acquisition - such as occupation of terra nullius or prescription - are categorized as the third stage. The two other traditional modes of acquiring title to territory are conceptually different but in practice difficult to differentiate in the case law, ${ }^{247}$ primarily because courts and tribunals rarely categorize title acquisition in terms of either occupation or prescription as such but rather focus on the elements of effective control. ${ }^{248}$ In other words, the Tribunal and the Court evolved away from its origins in Roman law into something different, known as 'peaceful and continuous display of State authority' or 'effectivités.'249

Title to territory in disputed cases is decided essentially on the basis of a relative weighting of the arguments of the claimant parties. ${ }^{250}$ There is no absolute or fixed threshold of state activity that must be manifested before title can be recognized as subsisting in one party or another. Therefore, it is adequate for one party to demonstrate a claim that is stronger than that of another state. Where both claims are weak, the less weak of the two will suffice. ${ }^{251}$

Naval surveillance and patrol activities can be used as evidence of effectivités to determine whether acts cited by a party related to character. ${ }^{252}$ Evidence

247 Shaw, Title to Territory, supra note 186, at xix.

248 In Pulau Ligitan and Sipadan (Indon./Malay.), Franck suggested that the Court's comparison of the claimant's effectivités was not reasonable on the following grounds. To quote him, "It appears to me like trying to weigh precisely a handful of feathers against a handful of grass: it can be done, but not very convincingly." See Pulau Ligitan and Sipadan (Indon./Malay.) (Franck, J., dissent), para. 17.

249 Lesaffer, Randall, "Argument from Roman Law in Current International Law: Occupation and Acquisitive Prescription", 16 Eur. J. Int'l L. 25, 46-56 (2005).

250 Shaw, Title to Territory, supra note 186, at $x x$; Munkman, supra note 234, at 99.

251 Shaw, Title to Territory, supra note 186, at $x x$.

252 They can be taken as effectivités with regard to the disputed island only if it is clear from their effects that they pertained to the specific island. See Pulau Ligitan and Sipadan (Indon./Malay.), para. 139 \& 141 ("[T] he [same] activities relied upon by Indonesia do not constitute acts à titre de sourverain reflecting the intention and will to act in that capacity" because "it could not be deduced from documents in connection with Dutch or Indonesian naval surveillance and patrol activities that the naval authorities concerned considered Ligitan and Sipadan and the surrounding waters to be under the sovereignty of the Netherlands or Indonesia."). See also Eritrea-Yemen Arbitration (Phase I: Territorial 
of effective administration or of regulatory and administrative assertions of authority over territory can include such measures taken to regulate and control the collection of turtle eggs and the establishment of a bird reserve, ${ }^{253}$ the organization of public health and education facilities, policing, and the administration of justice, ${ }^{254}$ licensing of activities in the waters off the islands, ${ }^{255}$ the arrest of fishing vessels, ${ }^{256}$ the granting of permission to cruise around or to land, ${ }^{257}$ the maintenance of naval and coast guard patrols in the waters around the islands, ${ }^{258}$ the establishment of military posts on the islands, and the exercise of criminal or civil jurisdiction in respect to happenings in the islands. ${ }^{259}$

Conversely, the probative power of the following activities depends on certain special circumstances. The construction and operation of lighthouses and navigational aids is not normally considered a manifestation of State authority. However, in the case of Territorial Questions (Qatar v. Bahr.), the Court stated "The construction of navigational aids, [-----], can be legally relevant in the case of very small islands. In the present case, taking into account the size of Qitat Jaradah, the activities carried out by Bahrain on that island must be considered sufficient to support Bahrain's claim that it has sovereignty over it." ${ }^{260}$ With regard to the publication of notices in connection with the installation of new lighthouses in the islands, the Tribunal considering Eritrea-Yemen Arbitration (Phase I: Territorial Sovereignty) noted "[S]uch notices [------] do not generally have legal significance. ${ }^{261}$ However, the issuance of such notices,

Sovereignty), paras. 239 \& 241 (“[T]he factual evidence of 'effectivités' presented to the Tribunal by both parties is voluminous in quantity but is sparse in useful content, because "it is replete with assertions of sovereignty and jurisdiction that fail to mention any islands whatsoever, and with general references to the 'islands' with no further specificity.").

253 Pulau Ligitan and Sipadan (Indon./Malay.), paras. 132-45.

254 Land Boundary (Cameroon v. Nig.), para. 67. While the Court admitted that these state's acts "could normally be considered to be acts à ttire de sourverain," it concluded that the situation was essentially one where the effectivités adduced by Nigeria did not correspond to the legal title (para. 70). The reason is that Cameroon had already had the legal title to disputed territory and there was no acquiescence by Cameroon in the abandonment of its title in the area in favour of Nigeria (paras. 68-70).

255 See Eritrea-Yemen Arbitration (Phase I: Territorial Sovereignty), paras. 258-63.

256 See Ibid., paras. 264-73.

257 See Ibid., paras. $275^{-80}$.

258 See Ibid., paras. $287-311$.

259 See Ibid., Paras. 335-40.

260 Territorial Questions (Qatar v. Bahr.), para. 197. The Court was of the view that the same considerations applied in the Pulau Ligitan and Sipadan (Indon./Malay.) (para. 147).

261 Eritrea-Yemen Arbitration (Phase I: Territorial Sovereignty), para. 283. 
while not dispositive of the title, nevertheless supposes a presence and knowledge of location. ${ }^{262}$

Lastly, certain activities cannot prove sovereignty. For example, activities by private persons such as fishermen cannot be seen as effectivités if they do not take place on the basis of official regulations or under governmental authority. ${ }^{263}$ In other words, "it does not constitute evidence of effectivités for the simple reason that none of these functions are acts à titre de souverain." 264 Concerning the acts of search and rescue, the Tribunal of the Eritrea-Yemen Arbitration (Phase I: Territorial Sovereignty) held that "Since there is under the law of the sea a generalized duty incumbent on any person or vessel in a position to render assistance to vessels in distress, no legal conclusions can be drawn from [them]."265 Also the act of over-flying a substantially deserted group of islands is not one that would appear to constitute with any cogency an intentional display of power and authority over them. ${ }^{266}$

In brief, the Tribunal and the Court have considered the following points when deciding if a country has exercised dominium or sovereignty over a disputed territory, on the basis of effectivités. Firstly, it must be proved that the state's authority was exercised in an effective, continuous, peaceful and sufficient way. ${ }^{267} \mathrm{~A}$ private act, independent to the exercise of governmental authority, cannot be used to prove dominium of the country to which the private act was attributed. ${ }^{268}$ Secondly, governmental authority can be exercised by various degrees and forms, according to special conditions of the targeted territory in dispute. Thirdly, the Court decides to which state the disputed territory belongs, even by an unnoticeable degree of effective control, after evaluating proof concerning the exercise of a state's authority. Fourthly, the Court presumes that the currently occupying state has the right to the title to the territory; as a result, if the non-occupying state cannot plead a strong rebuttal, the decision will not be in favor of the non-occupying state - even though it seems to hold, by a narrow margin, a relatively superior position in the comparative weight of effective control. Lastly, proof that the Court will

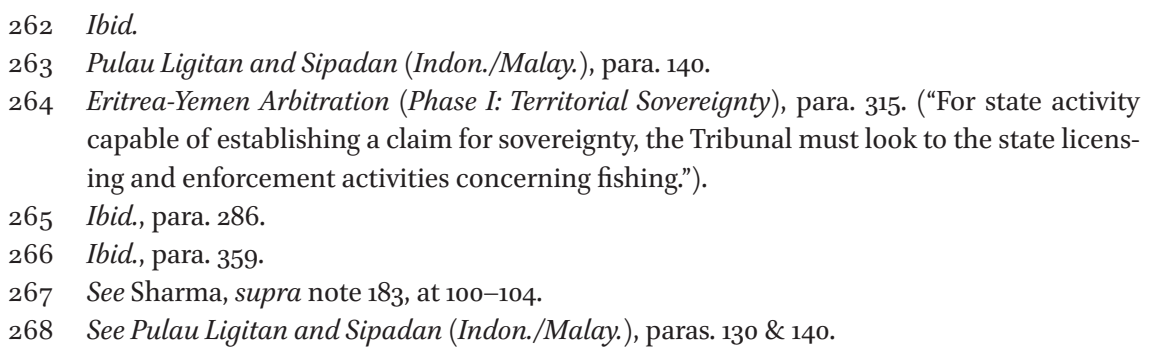
capable of establishing a claim for sovereignty, the Tribunal must look to the state licensing and enforcement activities concerning fishing.").

265 Ibid., para. 286.

266 Ibid., para. 359.

267 See Sharma, supra note 183, at 100-104.

268 See Pulau Ligitan and Sipadan (Indon./Malay.), paras. 130 \& 140. 
evaluate in terms of evidentiary value must be directly related to the possession of the disputed territory. 269

\subsection{Jurisprudence and Rationales of the "Three-Staged Judicial Review"}

The Tribunal and the Court adjudicate issues of sovereignty on the legal basis and review the claim of effectivités of the one Party compared to the acquiescence, recognition or preclusion (estoppel) of the opposing Party. The legal basis of territorial sovereignty can be divided into two categories: assessment of boundary treaties, peace treaties, the principle of uti possidetis, and an adjudication award; and, investigation of a chain-of-title through cession and succession. A remarkable difference between the two categories exists even though both are legally based so that the Tribunal and the Court should review them before reviewing the effectivités and acquiescence, recognition or preclusion (estoppel). Considering a hierarchy between the former and the latter, once a boundary has been established or a territory has been apportioned by the former, it cannot be modified by the latter. Further, when the Tribunal and the Court determine a sovereignty issue, the former is the only decisive evidence and conversely, the latter is the type of evidence which the Tribunal and the Court are unwilling to seriously consider.

Tracking a chain-of-title through cession and succession is of no value when it purports to base the claim on some distant historic connection with the territory which has in fact long been superseded by the effects of later historical developments - the emergence of a modern state as a governance form (as we see in Eastern Greenland (Den. v. Nor.) and Minquiers and Ecrehos (Fr. v. U.K.)) or the forced inflow of a modern state by Western influences through colonization (as we see in Territorial Dispute (Libya/Chad), Land, Island and Maritime Frontier Dispute (El Sal. v. Hond.), and Eritrea-Yemen Arbitration (Phase I: Territorial Sovereignty)).

Three reasons exist for the reluctance of the Tribunal and the Court to grant territorial sovereignty based on a chain-of-title through cession and succession from ancient times. Firstly, it is very difficult to prove that all former entities involved in the chain-of-title through cession or succession intentionally displayed power and authority over the territory. Because Since the former can

269 In Pulau Ligitan and Sipadan (Indon./Malay.), the act of the Netherlands Navy, for example, to patrol the sea and air around disputed islands for the purpose of suppressing pirates was to be regarded as an exercise of governmental authority because it was done under the auspices of that state's agencies. However, the act was not for the disputed islands specifically, and therefore, did not contribute to proving control in a way that was effective enough to be admitted the title of Indonesia (Netherlands' successor). 
transfer to the latter no more rights than actually possessed, the title claimed by the ceding or predecessor state should be proved as a non-defective title in order to show that the state to which the territory is ceded or succeeded will also retain the intact and valid title.

Secondly, the judicial review of historical chain-of-title tends to open the door for non-legal claims, which directly relates to the effect of colonialism and conquest on a current status of a territory at issue. The Tribunal or the Court which takes into account its own standing and reputation whenever it issues an award or a decision, does not want to be seen as acting as a proxy to re-impose colonial rule. Conversely, to render void any title established at a time when conquest was a legal mode of acquiring territory and to revert the title to a successor state of an alleged original owner could seriously damage the stability of boundaries.

Lastly, the framework of the current international law of territorial acquisition demands that the entity alleged to have sovereignty should be a 'state' and the state should exercise 'State functions' over the territory in order for the Tribunal and the Court to recognize territorial sovereignty of an entity. Clearly, a society that did not mirror the structure and model of a modern state, is regarded as having no sovereign rights over the territories. Example of this type of society include the dynastic and feudal governance form of early European society as well as organized groups of peoples on other continents as long as they did not conform to the model of a modern state. Even if there is some nuance by which the Tribunal and the Court consider an entity other than a state as the territorial sovereignty, it could not admit that the ties of personal allegiance between non-Western cultural and religious entities and inhabitants would fall within the category of the category of the ability to exercise of sovereign authority.

In the absence of any legal title, the principle of effectivités must invariably be considered. Title to territory in disputed cases is determined essentially on the basis of a relative weighing of the arguments of the claimant parties. It is adequate for one party to demonstrate a claim that is stronger than that of another state. Where both claims are weak, the claim that exhibits the lesser weakness will suffice. If there is a fixed threshold of minimum effectivités, it is the recognition, acquiescence or estoppel of the opposing party. While the grant of title in the first stage of the "three-staged judicial review" will be likely to cause non-compliance of the ICJ Judgment if one party occupies territory awarded to the other side, there is no need for action by the other side or a judicial body if the territory is already in possession of the state declared to be entitled to title in an award or decision. 
There are three rationales that the Tribunal and the Court follow the "three-staged judicial review." Firstly, from the light of a legal principle, it can be stated that the principle of stability of boundaries is the most primary concept and it may defeat other principles of international law that support de-colonization.

In addition to the substantial law concerning territorial disputes, the need to observe the procedure from the first stage of instituting a lawsuit to the last stage of enforcing a judgment was discussed because the judicial mechanism of international society did not reach the level worth trusting as much as that of domestic society. That is, because the jurisdiction of the Arbitral Tribunal and the Court is usually based on the consent of two disputant countries rather than compulsory jurisdiction, Parties agreed upon compromis or reached a special agreement in advance in most cases.

An international judicial institution such as the ICJ takes care to secure its reputation that its judgment should be respected and complied with by parties. Therefore, if there is no legal basis concerning the title of territory in issue, a judicial body prefers to decide sovereignty on the basis of the principle of effectivités, for the ruling grounded on principle of effectivités has no need to be enforced by a third authority - in other words, maintaining the status quo itself equates to compliance with the judgment.

The reasoning of the currently international decision of territorial acquisition demonstrates that the Tribunal and the Court actually restricts the scope of its judicial review to a boundary treaty, a peace treaty, the uti possidetis juris, an adjudication award and effectivités rather than a chain-of-title from ancient times. Such reasoning generates suspicions and doubts in Third World countries that international law and the authority to apply international law to specific cases are biased toward maintaining past colonial rule under the guise of the stability of boundaries. On the other hand, it is justified by the 'law and economics approach' applicable to domestic real property law.

\section{5 \\ Application of the "Three-Staged Judicial Review" to the Territorial Issue regarding the Liancourt Rocks}

Previously, the "three-staged judicial review" existing in the reasoning of territorial dispute decisions and its underlying policies were discussed. The application of this process to the territorial issue regarding the Liancourt Rocks is now considered. As stated previously, Korea claims title to the Liancourt Rocks on the basis of discovery and succession, as well as effectivités. Conversely, Japan claims dominium over the Liancourt Rocks on the basis of 
the San Francisco Peace Treaty, and the permission by the Japanese government for private activity in the 17th century and its internal notification of incorporating the Liancourt Rocks shortly before annexing all of Korea in 1910.

When the "three-staged judicial review" process is applied to the territorial issue regarding the Liancourt Rocks, the content of the San Francisco Peace Treaty would be viewed as the primary subject matter. During the negotiation process of the Peace Treaty, the issue of whether Japan should relinquish the Liancourt Rocks to Korea because Korea was the original owner of the island before Japan's aggression was discussed. However, the Liancourt Rocks was not specifically referenced among the islands that Japan should renounce and therefore, over which Korea should have title. That is, Article 2 of the Treaty simply states that "Japan, recognizing the independence of Korea, renounces all right, title and claim to Korea, including the Islands of Quelpart, Port Hamilton and Dagelet." Japan argues that this Article means that Japan did not renounce the island and therefore it is still Japanese territory. Conversely, Korea claims that the island was replaced according to the above Article. According to Korea's argument, the island has continuously belonged to Korea since 512 A.D. and the islands mentioned in the Peace treaty should be seen as illustrative rather than enumerative given the large number of islands scattered around the Korean Peninsula.

The Parties of the Peace Treaty intended to compel Japan to return territory acquired through imperial aggression to its original owner. If they had been sure that the Liancourt Rocks belonged to Korea, they would have made the provision for Japan to renounce it. Therefore, does the absence of the provision that Japan shall renounce the Liancourt Rocks means that the Parties were sure that it belonged to Japan and they assigned it to Japanese territory?270

270 Recently, it has been recognized that the text of the San Francisco Peace Treaty may not be interpreted in favor of Korea (Lee, Seok Woo, "The Legal Status of the Kurile Islands and the Senkaku Island in the San Francisco Peace Treaty, and Their Implications on the Territorial Dispute over the Liancourt Rocks", g Seoul International Law Journal 45 (Fall 2002); Lee, Seok Woo., "International Law and the Resolution of Territorial Disputes over Islands in East Asia", Doctoral thesis of University of Oxford (2001); Lee, Seok Woo, "The San Francisco Peace Treaty with Japan of 1951 and the Territorial disputes in East Asia", 11 Pacific Rim L. \& Pol'y J. 63-146 (2002)), because its preparatory work definitely shows that the United States, the principal party of the treaty, considered the Liancourt Rocks as Japanese territory. ("Takeshima (the Liancourt Rocks) - The two uninhabited islets of Takeshima, almost equidistant from Japan and Korea in the Japan Sea, were formally claimed by Japan in 1905, apparently without protest by Korea, and placed under the jurisdiction of the Oki Islands Branch Office of Shimane Prefecture. They are a breeding ground for sea lions, and records show that for a long time Japanese fisherman migrated there during certain seasons. Unlike Dagelet Island a short distance to the 
However, according to the preparatory works of the Peace Treaty, the Parties, including the United States of America, could not know with certainty whether Korea or Japan was the original owner of the island prior to Japanese imperial aggression. Therefore, it is correct to interpret the territorial provision to mean that the Allied Powers, including the U.S.A., and Japan did not intend to deal with the matter so they deferred it to a peaceful diplomatic settlement between Korea and Japan. ${ }^{271}$ Furthermore, it is apparent from the subsequent

west, Takeshima has no Korean name and does not appear ever to have been claimed by Korea." ("Commentary on Draft Draft Treaty of Peace with Japan" in 1949/12/29, [USNARA/ Doc. No.:N/A] reprinted in Liancourt Rocks' Document, supra note 39, at 160-61). See also 1949/11/14 [USNaRA/740.0011 PW (Peace)/11-1449], US Department of State, "Incoming Telegram by William J. Sebald (U.S. Political Adviser for Japan) to Secretary of State", reprinted in Liancourt Rocks' Document, supra note 39, at 178)). Therefore, it seems quietly likely to conclude that the Peace Treaty may be disadvantageous to Korea's claim to the Liancourt Rocks.

271 It is reasonable to interpret that the Peace Treaty withheld a disposition about which state has sovereignty over the Liancourt Rocks. The preparatory work of the San Francisco Peace Treaty indicate that the parties of the Peace Treaty agreed not to decide the sovereign state of the Liancourt Rocks, and to leave the potential territorial dispute to the autonomy of two concerned countries (“--- We had never heard of Dean Rusk's letter to the Korean Ambassador in which the Department took a definite stand on this question.... We were subsequently made award of the fact that Article 2(a) was not to be amended but had no inkling that that decision constituted a rejection of the Korean claim. Well, now we know and we are very glad to have the information as we have been operating on the basis of a wrong assumption for a long time." (1952/12/4 [USNARA/ Doc. No.: N/A], US Department of State, "A Letter from Mr. E. Allan Lightner, Jr. (Charge D'Affaires, ad interim, US Embassy in Korea) to Mr. Kenneth T. Young, Jr. (Director, Office of Northwest Asian Affairs)," reprinted in Liancourt Rocks' Document, supra note 39, at 199). "Despite US view peace treaty a determination under terms Potsdam Declration and that treaty leaves Takeshima to Japan, and despite our participation in Potsdam and Treaty and action under Administrative Agreement, it does not necessarily follow US automatically responsible for settling or intervening in Japan's international disputes, territorial or otherwise, arising from Peace Treaty." (1953/12/8 [USNARA/694.95B/11-2353], US Department of State, "Outgoing Telegram to US Embassies in Korea and Japan by Johan F. Dulles," reprinted in Liancourt Rocks' Document, supra note 39, at 208-209). See also 1953/7/22 [USNARA/694.9513/7-2253], US Department of State, "Office Memorandum: Possible Methods of Resolving Liancourt Rocks Dispute between Japan and the Republic of Korea," reprinted in Liancourt Rocks' Document, supra note 39, at 201-202), - although in the process of negotiation the United States, one principal party in the Peace Treaty, was convinced that the Liancourt Rocks belonged to Japan.

Even if the preparatory work of the Peace Treaty is proved to disadvantageous against Korea, its preparatory work is only a supplementary means of treaty interpretation. In other words, it is difficult to assume that the preparatory work has definitive and decisive evidential power. When a wording of a treaty concerning a territory is unclear and ambiguous, the Courts can use the presumption that subsequent acts may have been done to correspond to the wording of the Peace Treaty. (Shin, Kak-su, "Study concerning 
response of the USA to the conflict over the island of Liancort Rocks. The U.S.A. recommended that two concerned states refer the territorial dispute to the ICJ, maintaining that the San Francisco Peace Treaty did not provide any answer to the title problem. Although there is a presumption that the Tribunal and the Court will favor an interpretation of a treaty creating a boundary that holds that a permanent, definite and complete boundary has been established, it cannot apply to this case. The Treaty, its preparatory document, and subsequent conduct of its parties manifested an intention that it never established or recognized the territorial sovereignty, specifically designating one country. 272

the Settlement of Boundary Disputes on the Basis of International Law", Doctoral Thesis of Law Graduate, Seoul National University 74-75 (1991)). The subsequent act - like Korea's effective control over the Liancourt Rocks - can be considered more valuable in interpreting the Peace Treaty than the preparatory work. In addition, the Article 32 of the Vienna Convention on the Law of Treaties (Vienna Convention on the Law of Treaties (May 23, 1960), 1155 U.N.T.S. 331) provides that the preparatory work made in the process of negotiation is only a supplementary means of interpretation. (Article 32 of the Vienna Convention on the Law of Treaties concerns the usage of supplementary means of interpretation, restricting reliance on such sources as follows: "Recourse may be had to supplementary means of interpretation, including the preparatory work of the treaty ---, in order to confirm the meaning resulting from the application of Article 31, or to determine the meaning when the interpretation according to Article 31: (a) leaves the meaning ambiguous or obscure; or (b) leads to a result which is manifestly absurd or unreasonable."

Concerning the role of preparatory work as supplementary means of interpretation and the comparison of relative weight of preparatory work and subsequent practice, see "Interpretation in International Law", E PIL, Vol. II, at 1420-21; Rosenne, Shabtai, "Travaux Préparatoires", 12 Int'l \& Comp. L. Q. 1378 (1963); Lauterpacht, H. "Some Observations on Preparatory Work in the Interpretation of Treaties", 48 Harv. L. Rev. 549 (1934-35); Briggs, Herbert W., "The Travaux Préparatoires of the Vienna Convention on the Law of Treaties", 65 Am. J. Int'l L. 705 (1971); Ris, Martin, "Treaty Interpretation and ICJ Recourse to Travaux Préparatoires: Towards a Proposed Amendment of Articles $3^{1}$ and $3^{2}$ of the Vienna Convention on the Law of Treaties", 14 B.C. Int'l \& Comp. L. Rev. 111 (1991)). Therefore, the preparatory work can be cited to support a decision in favor of Japan, but only when the Court decides to award Japan's sovereignty on the basis of some other kind of evidence. The Courts cannot admit Japan's sovereignty over the Liancourt Rocks on the basis of the preparatory work itself solely. (See Miller, Robert W., "Preparatory Work in the Interpretation of Treaties", 17 Iowa L. Rev. 206, 222 (1931-32)).

For the reasons stated above, it is clear that the San Francisco Peace Treaty would be considered to have no provision for the status of the Liancourt Rocks, and that the court will not regard the treaty as conclusive evidence for the title on the Liancourt Rocks.

272 The treaty can be decisive on the issue of territory title on the Liancourt Rocks. (See Lee, Seok-Woo, "Some Observations on the Territorial Disputes over the Tokdo (the Liancourt Rocks) and the Interpretation of the Territorial Clauses of the San Francisco Peace Treaty", 9 Seoul International Law Journal 121, 136-37 (Spring 2002)). However, the up-to date precedents show that the Courts did not expand the intention of the Parties 
Therefore, the court will not regard the treaty as dispositive evidence for the title on the Liancourt Rocks if both parties refer it to the Tribunal or the Court.

Although Korea's argument for a chain-of-title based on succession seems more persuasive than that of Japan, it leaves doubt that the Court would grant title on the basis of historic title because of the difficulty of proving that all states in the chain-of-title had sovereignty over the Liancourt Rocks. Furthermore, according to the principle of inter-temporal law the Court must recognize the consequences of Japanese conquest and colonization, but considering the Court's reputation as guarantor of justice and the rule of law, it would try to avoid reviewing, insofar as possible, a chain-of-title from ancient times which necessarily leads to revealing the illegitimate but not thenillegal act and recognizing its consequences. The Tribunal and the Court assign weight to a modern state's sovereign acts according to precedents. In other words, other kinds of governance (e.g., regional allegiance) by other kinds of entities (e.g., feudal state, non-western dynasty, or African tribe) have never produced any positive conclusions regarding sovereign titles over territories. Actually the Tribunal and the Court simply have held that this kind of control over territory is not the relatively recent history of use and possession that ultimately proved to be a main basis of the decision. However, it can be boldly said that international law concerning territorial acquisition is most desirably applicable only to European "Civilized" states or state of European origin and actions taken only by them would relate directly to a ruling, even though the Tribunal or Court is not explicitly referring to this.

Although proof presented by Korea and Japan might have evidential power and reliability, the Court would exclude the proof so that the proof cannot affect the Court's ruling of territorial sovereignty, holding that "such an original title must have lapsed as a consequence of the events of the following years."273 The reasoning of precedents rather persuades non-European or colonized nations in the past to predict this scenario than to keep them from a negative attitude toward the Court in the international society. Regrettably for Korea, if the Court would decide sovereignty over the Liancourt Rocks on the basis of balancing the weight of effectivités, it would focus on a consequence of the measures having been taken since each Korea and Japan adopted the governance form of a modern state.

of the peace treaty or the treaty concerning boundary delimitation (For example, EritreaYemen Arbitration (Phase I: Territorial Sovereignty) and Pulau Ligitan and Sipadan (Indon./ Malay.)), nor did it presume "the conclusiveness and completeness of defined frontiers." See Pulau Ligitan and Sipadan (Indon./Malay.) (Franck, J., dissent), para. 36-46.

273 Minquiers and Ecrehos (Fr. v. U.K.), at 56. 
A Western-style modern state was transplanted in Japan and Korea in 1868 and 1882, respectively. Japan began civilizing (Europeanizing or westernizing) itself earlier than Korea. Instead of helping its Asian neighbors to revise their unequal treaties with European countries and achieve their independence as the first successful non-European nation, Japan learned the art of domination and colonization from the Western states and surpassed them all in suppressing its neighboring states. Strategically situated, Korea first fell victim to the Japanese imperial structure. Conversely, during the Chosun Dynasty that ended in 1910, Korea was slower to learn lessons from abroad and adjust its whole system than Japan, and it paid the price for its inability to compete with Japan that actively learned from the Western powers.

Japan well-recognized the truths concerning the abuse of international law by the strong nations and exploited their advantage in employing international law in Korea over forceful conquest (i.e., 1876 Unequal Treaty, 1905 Protectorate Treaty, and 1910 Annexation Treaty). Japan's Incorporation Measure of 1905 with regard to the Liancourt Rocks is Japan's strongest basis of title over the island and serves as but one example of exploiting international law against Korea. The Incorporation Measure was generated in the process of colonizing Korea. According to the current reasoning of effectivités, the effective exercise of sovereign authority means an intentional display of 'Power' over the territory, and therefore, Japan would have the advantage of proving effective exercise of sovereignty over the island during the process of becoming a imperial power over Korea.

Korea is optimistic about the outcome of a future judicial settlement on the basis of physical occupation. However, physical occupation in itself is not effectivités, one of the modes of territorial acquisition. In other words, effectivités involves more than physical occupation. Acquisition of territory based on effectivtiés requires that there be an intentional display of power and authority over the territory on a continuous and 'peaceful' basis. Additionally, at a minimum, it also requires acquiescence, recognition, or estoppel by the other party. ${ }^{274}$ Accordingly, it is not certain that the mere fact that Korea is

274 As we see in Pulau Ligitan and Sipadan (Indon./Malay.) the Court decided in favor of Malaysia which proved that its title had been recognized by Indonesia and Netherlands, its predecessor. In this case the Court used the criteria of effectivités to a minimum standard so that Judge Franck severely criticized that the Court's relative weighing of evidence submitted by Indonesia and Malaysia looked like comparing the weighing the effectivités adduced by Indonesia and Malaysia to weighing precisely a handful of feathers against a handful of grass. Even the case ascertained whether Indonesia made acquiescence or recognition with regard to Malaysia's alleged effective exercise of state authority over the two islands. 
now physically occupying the Liancourt Rocks will guarantee the title because Japan, a rival claimant by its protests or refusal to acquiesce, has inhibited Korea's acquisition of the island by 'acquisitive prescription' or 'effectivités.' Furthermore, even if the San Francisco Peace Treaty did not provide a provision about sovereignty over the island, the intention of the treaty is to restore the territorial title to that which existed at the moment immediately prior to Japan's imperial expansion into Korea. In other words, the clock was intended to stop at that time and the Liancourt Rocks was supposed to belong to the nation that had sovereignty over it. Only then if exercising a state's authority would be provable, the nation can be said to have legal title based on the object and purpose of the Territorial Articles of the Peace Treaty. The rights of the parties and the existence of dispute over the island had already crystallized so that Korea's acts following independence cannot alter the legal position because they were taken by Korea after the critical date and it would rarely be considered purely a normal continuation of prior acts.

However, it is difficult as well to say conclusively that Korea would lose the case as the result of the third stage of the "three-staged judicial review." Firstly, the fact that the colonization over Korea was instituted by Japan justifies the circumstances for the absence of the formal and official protest on the side of the Korean government against the Japanese activities. As the entire country was being robbed of its sovereignty, the problem of the title to a small rocky island did not receive priority. More importantly, the newly established Korean Empire promulgated Imperial Ordinance No.41 of the Korean Government of which Article 2 expressly designated a new Ullung county to administer the Liancourt Rocks in 1900. This occurred five years earlier than Japan's Incorporation Measure of 1905 with regard to the Liancourt Rocks.

Secondly, Korea's physical occupation of the Liancourt Rocks in the present day, continuing since Korea's independence, would bring Korea to expect to have the advantage in that the Court will be unlikely to order the withdrawal of Korea from the Liancourt Rocks. The Right of Passage over Indian Territory case $^{275}$ suggested that the Tribunal or Court does not want to be seen as acting as a proxy to re-impose colonial rule although the re-imposition of colonial rule is justified by the inter-temporal law ${ }^{276}$ and that the colonized party

275 See Case concerning Right of Passage over Indian Territory, 196o I.C.J. 6 (April 14) [hereinafter referred to as "Right of Passage over Indian Territory (Port. v. India)"], at 45-46 ("The Court finds - that Portugal had in 1954 a right of passage over intervening Indian territory ... (underlined by an author).").

276 In the view of the Court, the Portuguese application had referred to 1954 as the decisive date, not to the date of the application or that of the judgment; hence it held that Portugal 
would have more protection if it embarrassed the imperialist party even by use of force than by working diplomatically and quietly through the current international law system (e.g., referring the dispute to the ICJ).

Therefore, given Japanese imperial power over the entire Korean peninsula as well as the Liancourt Rocks between the end of the 19th century and the middle of the 2oth century, Korea's desperate and persistent efforts to recover its claim over the island immediately upon its independence, and ICJ's concern about being seen as a proxy to the re-imposition of Japanese colonial order, the Court may try to refer to this situation which may require special historical consideration, equity and justice when reviewing effectivités of the third stage. In consequence, Korea can be assured to win the case with a fair possibility.

merely wished to have a finding for the past, but not for the present. The judgment explicitly left open whether the right in question might have lapsed as a result of the events of July and August 1954 (Right of Passage over Indian Territory (Port. v. India), at 29), which, according to the Court, "brought about a new situation (Ibid., at 28)." It maintained that Portugal had not indicated an exact date in relation to which the existence of the right of passage was to be ascertained, but since the dispute was a consequence of obstacles to passage created by India in 1954, Portugal's application had to be understood as relating to times before the creation of these obstacles (Ibid., at 28-29). The reasoning of the Court might raise doubts: Portugal's claims had always been unambiguously formulated in the present tense. Its claims were not only retrospective in character, but also directed to the present and future (Schulte, supra note 93, at 120). Portugal sought a resolution of the current conflict, not a judgment on the past. The Court failed to rule on the subject-matter of the application, and its interpretation contravened the explicit intentions of the applicant (Verzijl, J.H.W., "The International Court of Justice, 1960, I. Case concerning right of passage over Indian territory (Portugal v. India), Merits", 7 Nederlands Tijdschriftvoor Internationaal Recht - Netherlands International Law Review 211, 217 \& 219 (1960); reprinted in Schulte, supra note 93, at 120). In view of the unequivocal wording, there was little need for interpretation, and if the Court had doubts, these should have been clarified during the oral proceedings (Schulte, supra note 93, at 120). One can hardly assume that Portugal referred to a time prior to the date of the application, but surely not July 1954 (Right of Passage over Indian Territory (Port. v. India) (Klaestad, J., declaration), at 47; Right of Passage over Indian Territory (Port. v. India) (Fernandes, J., dissent), at 125. A likely reason for the Court's restrictive approach was its reluctance to decide on the delicate issues concerning the current status of the enclaves, which directly related to the question of colonialism. The Court did not want to be seen as acting as a proxy to reimpose colonial ruled by the Portuguese (Bains, India's International Disputes, at 190-91; reprinted in Schulte, supra note 93, at 120). Judge Moreno Quintana voiced a clear opinion in this respect: "To support the Portuguese claim in this case, which implies survival of the colonial system, without categorical and conclusive proof is to fly in the face of the United Nations Charter." Right of Passage over Indian Territory (Port. v. India) (Moreno, J., dissent), at $88 \& 95$. 
Here Korea's strategy on the issue of the Liancourt Rocks will be studied. If potentially disastrous regional consequences could result, further driving a wedge between Korea and Japan, a redirected diplomatic effort to curtail that threat before it becomes a reality can be necessary. Given this situation of direct confrontation around the Liancourt Rocks between Korea and Japan, Korea's policy of 'no dispute over Dokdo (the Liancourt Rocks)' is hardly a recipe guaranteeing a title. Instead of risking a war between Korea and Japan, Korea should embrace the opportunity to advance its broader strategic goals of overcoming past suffering and promoting reconciliation, stability and prosperity between the two nations. Korea best serves its long-term security interests by acting wisely and proportionately. Korea and Japan should adopt a winwin approach to the Laincourt Rocks issue by promoting the negotiation of applicable law which is the proper solution to reconciliation between the two states. That is, of course, far easier said than done. Negotiating a compromis or special agreement involves a number of related issues, including establishing the critical date, for example, and determining applicable law such as the principle of de-colonization. An agreement concerning the law applicable to the territorial issue regarding the Liancourt Rocks prior to referring the matter would bridge big gaps between Korea and Japan on how to handle the issue.

Before consenting to refer the matter to the Tribunal or the Court, Korea must note that Korea and Japan should agree to create an international law concerning territorial disputes that is not imperial; that can, in fact, further justice without relapsing into the imperial project"277 in order for Korea to guarantee that Korea would win the case, considering the remnants of past injustices are more tolerantly viewed as acceptable phenomena according to the principle of inter-temporal law. ${ }^{278}$

Here, it is proposed that it would be desirable for the would-be Court referred to by Korea and Japan to settle territorial disputes on the basis of

277 Ibid., at 317.

278 For a detailed description of colonial legacy deeply implanted in contemporary international law, see Anghie, Antony, “The Heart of My Home': Colonialism, Environmental Damage, and the Nauru Case", 34 Harv. Int'l L. J. 445 (1993). Anghie argues that "international law continuously attempts to efface its complicity with colonialism (Ibid., at 241)," that "colonialism is somehow pervasive, foundational in international law (Ibid., at 243)," that "the Imperial character of international law is disregarded even when it is being reproduced in a way that powerfully shapes contemporary international relations (Ibid., at 250)," and that "colonialism was central to the constitution of international law and sovereignty doctrine (Ibid., at 310)." 
oriental wisdom, not on Western traditions that justify the imperialist mode of territorial acquisition. ${ }^{279}$ Korea must lead Japan to accepting the idea that the justice Korea will seek is appropriate, not positive international law which is advantageous for imperialist colonialists. ${ }^{280}$

The applicable law provision agreed upon between Korea and Japan will transform the sense of justice and reconciliation in the international law with binding force, and only then will both parties be able to refer the issue to the Tribunal or the Court with the expectancy of reconciliation and justice.

Generally, it is recognized that changing circumstances or the passage of time can have an effect on ownership rights notwithstanding the moral legitimacy of the original appropriation. Therefore, after several generations beyond the age of imperialism, past injustices may not seem to be worth correcting. However, some injustices, resulting from past colonialism, are not superseded with the passage of time and special measures are needed if they are to be redressed satisfactorily.

The applicable law provision agreed upon by Korea and Japan may focus on the chain-of-title through succession from the ancient times, excluding the evidence related to the attempt and the act of the imperial expansion of Japan and establishing a critical date prior to the date on which Japan began its imperial intrusion into Korea. In addition, both parties would select arbitrators who understand the regional international law in the Confucian culture and can read Chinese Character in the old maps and old documents which will be of decisive importance in determining which country displayed sovereignty over the Liancourt Rocks and which country recognized, or at least acquiesced to the sovereignty of the other. ${ }^{281}$

\section{See Ibid., at 84. \\ 280 Ibid., at 86.}

281 Because current international law places a priority on legal order and stability over justice, there is little possibility that the court will reach contrary result by understanding an oriental international law in the past time and thus reverse the consequences of colonialism. However, the consideration of boundaries and territorial sovereignty from a Confucian perspective will help the court to evaluate the weight of acts of former 'states (mainly having the form of dynasty)' in Asia and then draw a conclusion by reviewing a chain-of-title from ancient times if the Tribunal and Court is authorized to do by Korean Japan.

(1) Confucian Ideal: In an ideal world, there would be no territorial boundaries between states. One sage-king would govern over the whole world, relying solely on moral power to secure people's compliance with virtue. The ideal of a unified Confucian state spreading Humanity to the whole world began to be taken more seriously following the creation of Imperial China (See Hsu, Immanuel C. Y., China's Entrance into the Family of Nations 6 (Cambridge: Harvard Univ. Press, 1960)). From the Han Dynasty (206 BC$220 \mathrm{AD}$ ) onwards, the "Middle Kingdom" saw itself as the largest and most powerful 
Based on the explicit expression of state intent, the lex posgerior principle and the lex specialis principle, the applicable law agreed upon by Korea and Japan will preclude an adjudicator or a judge from applying general international law concerning territorial acquisition. In this case, Korea and Japan involved in a territorial issue will jointly benefit given that both countries could avoid the military conflict. In addition, Japan will fulfill a moral obligation caused by historical wrongs as a constituent of the international society in that the worth of international society depends on the moral standing of the states of which it is constituted - while Korea will not feel anxious concerning

state in the world, spreading the benefits of Confucian civilization to the rest of the world. See Bell, Daniel, "The Making and Unmaking of Boundaries: A Contemporary Confucian Perspective", in States, Nations, and Borders (Allan Buchanan \& Margaret Moore (eds.), 2003)), at 66.

(2) Reality: Tributary system: In this system, the tributary ruler or his representative had to go to China to pay homage to Chinese overlordship by prostrating himself before the Chinese emperor in ritual acknowledgment of his vassal status. In return, China guaranteed security and provided economic benefits, while using "moral power" to spread Confucian norms. See Ibid.

(3) Porous boundary: Boundaries should be porous, and people should have the right to leave their homeland and start anew if they experience economic hardship. Gentlemen have a special obligation to leave their homeland and advise relatively benign foreign rulers, and common people should have the right to flee tyrannical rulers. See ibid., at 70 .

(4) Allegiance attachment: The establishment of title over territory was determined by control by virtue (moral power) (=the response of joy felt deeply in the heart) rather than physical occupation. The attachment to a settled place per se cannot justify the creation of state boundaries. Settlement alone might justify the acquisition of territory and the creation of state boundaries if people are attached to a territory and to the collectivity constituted by those whose ancestors were native to the territory and if this attachment overrides competing values in cases of conflict. Ibid., at 68).

(5) Conquest and Reversion: The territory must have been justly acquired in the first place - that is, by the peaceful exercise of "moral power." (Ibid., at 70) Therefore, conquered territory cannot justifiably be passed down to descendants (Ibid., at 70). (Cf. Western international law: Conquest and occupation over terra nullius (inhabited by non-European natives) were accepted as legal modality of territorial acquisition during pre-Charter era). There is an exception to this rule. Territory can be acquired and boundaries altered through conquest if, and only if, the aim is to secure peace. And this must be done in the following circumstances: (1) the conquered people are liberated from tyranny, (2) the people welcome their conquerors, and (3) the war is relatively "clean" and stands a good chance of success. (Ibid., at 73. Cf. In the western international law, conquest and colonialism were justified for the idea of the civilizing mission). It should also be added that Confucians leave open the possibility that the original inhabitants have rights to the conquered land or, at least, more rights than the occupier's descendants. (Ibid., at 7o. Cf. Even current [western] international law is very careful about accepting the notion of reversion). 
the potential bias of international legal system (international judicial bodies, international law, and reasoning in awards and judgments of territorial disputes) towards the maintenance of the boundary order resulting from past imperialism.

To understand the bargaining power of Korea and Japan, it must be noted that jurisdiction over disputes to territory is available only with the consent of the disputing states - that is, only if and when Korea and Japan have reached a political agreement on the composition, procedures and applicable laws, will the territorial issue regarding the Liancourt Rocks become subject to judicial settlement. ${ }^{282}$ Therefore, the state in physical possession of the disputed territory cannot be compelled to submit to any mechanism that might pass judgment on its legal claims and might order an overturn of the current situation. Accordingly, Korea's physical occupation of the Liancourt Rocks will be one of the most important bargaining chips in the negotiation between Korea and Japan concerning the matter of apportioning the territory or referring the territorial issue to judicial settlement. Conversely, Japan should provide an incentive to persuade Korea into negotiating a referral of the case of the Liancourt Rocks to a judicial body. Japan would be offered an opportunity of referring the issue to the Court, otherwise seemingly impossible or possible only after military conflict between the two countries and the pressure of international society and institutions, in exchange for verifiably abandoning the legal benefit arising from the consequences of the past imperialism. On the other hand, Korea would be offered the fair possibility of renewing its reputation from that of an illegal occupant to a legitimate owner through a new applicable law agreed upon by both Parties and based on the sense of historical justice, in exchange for the current benefit of physical occupation of the Liancourt Rocks, even though risking the loss of valuable territory.

Referral to arbitration may be preferable to referral to the Court because the parties involved in a territorial dispute can exercise broad latitude in crafting the arbitration compromis as it relates to the choice of law upon which the Tribunal may rely. An arbitration compromis can allow the Tribunal broad flexibility to rely on complex historical circumstances, the consideration of which enriches historical justice and fairness. Added to the flexibility in the parties' selection of the applicable law is the parties' appointment of judges more adjustable in arbitration than in the Court.

Korea may use its physical occupation over the Liancourt Rocks in the present as a bargaining chip in order to induce Japan to agree upon applicable law provision above mentioned. Japan will be able to succeed in persuading Korea

282 Lee, Han Key, supra note 5, at 84. 
to agree to a judicial solution to the territorial issue regarding the Liancourt Rocks, only if Japan would give a reminder that it is willing to step forward to reconcile with a neighboring state.

It must be noted that the scenario above mentioned apply to only emergency situation. If it is not the case, Korea does not need to negotiate with Japan a referral of the territorial issue. There are some reasons that it is considered reasonable for Korea to maintain that there has be no dispute concerning the island between Korea and Japan. Firstly, given that Korea police have occupied the island itself and its territorial sea of 12 nautical miles, and they protected Japanese vessels from entering into its territorial sea, Korea has maintained absolutely advantageous position over Japan with regard to the territorial issue. If Korea cannot assure that the probability for Korea to win the case is $100 \%$ because of alleged bias of the reasoning concerning territorial cases towards imperialism, there is no reason for Korea to give up this advantageous status and to be led by Japan with no special emergency.

Secondly, considering that Japan has the lowest value on the Liancourt Rocks among three territorial zones disputed by its neighboring states, the military conflict around the island would end to prove fearsome apparitions daubed by Japan. Korea has taken a small island comparing to the Northern Island and the island of Senkaku, and it is almost impossible for Japan to choose extreme measure to restore the Liancourt Rocks. Korean Government may give up the policy that there has no dispute with regard to the Liancourt Rocks between Japan and Korea if the alternative were direct confrontation with Japan. However, Japan could find many more reasons for persuading its people from engaging into war and for leaving Korea alone than fighting over the island of value. If so, Korea will never, by the award of arbitration or the decision of ICJ, give in to Japan what Japan could not get from Korea by direct confrontation which Korea expects would not be likely to happen, for the Tribunal and the Court contribute to the resolution of territorial disputes only if both parties can see mutual benefits (such as to avoid direct military conflict in this case) from using the international judicial system, given that Tribunals and ICJ will be able to exercise jurisdiction only if both parties consent to that. ${ }^{283}$

283 See Posner \& Yoo, "Judicial Independence in International Tribunals", 93 Cal. L. Rev. 1, 15 (2005). 
The claims of Korea and Japan to the Liancourt Rocks can be summarized in terms of the reasoning applied in territorial dispute decisions. Korea claims the Liancourt Rocks on the basis of discovery and succession, as well as effectivités. Conversely, Japan claims dominium over the Liancourt Rocks on the basis of the San Francisco Peace Treaty, the permission granted by the Japanese government for private activities in the 17 th century and its internal notification of incorporating the Liancourt Rocks shortly before annexing all of Korea in 1910.

To apply the three-staged reasoning to this case, the San Francisco Peace Treaty will be brought to the fore, but the Court would not regard the treaty as conclusive evidence for the title to the Liancourt Rocks because it did not specifically provide any provision concerning the island and it is certain that the real intention of the Treaty parties was to refer the matter for resolution by the governments of Korea and Japan. Next the historic or ancient title to be proved by the existence of a chain-of-title through succession and cession is inconsistent with the nature of territory, which evolves and changes over time, and for which a power-oriented, evolutionary law concerning territorial acquisition is uniquely appropriate. Because the nature of territory is completely obedient to the powers, the law of territorial acquisition does not, in all cases, "say what may be done." For this reason, the Tribunal and the Court would compare the relative weight of effectivités presented by both parties, concerned about its reputation as an authority whose awards or decisions should be respected.

To date, Korea has maintained that it is not a dispute worthy of mentioning because there is no doubt that Korea has territorial sovereignty over the Liancourt Rocks. Considering Korea's physical occupation over the island and the degree of Japan's willingness to reoccupy the disputed island, it is understandable for Korean Government to believe that it is the best strategy to ignore the Japanese territorial claim over the Liancourt Rocks and to make every effort to control the likelihood of international intervention which would probably entrust the island's status to the review of ICJ.

In the case of unexpected military emergency, however, it is recommended for Korea that Korea and Japan politically negotiate the law to be applicable to a territorial matter when both Parties agree to refer it to the Tribunal (preferable) or the Court in order to overcome the remnants of past colonial history. The applicable law provision may stipulate that a date prior to imperial invasion is a critical date and the determination of sovereignty should be on that 
critical date; that the Court should not grant sovereignty based on evidence related to the process of imperial expansion; and that the Court should focus on a chain-of-title established prior to the beginning of the colonial times, which, otherwise, will be easily overlooked by the Tribunal or the Court in the light of the current reasoning of territorial disputes. 